\title{
A Critical Review on Design and Development of Gas Sensing Materials
}

\author{
M.N. Padvi, ${ }^{1}$ A.V. Moholkar, ${ }^{2}$ S.R. Prasad ${ }^{3}$ and N.R. Prasad ${ }^{1, *}$
}

\begin{abstract}
The detection of gas molecule is important for environmental monitoring, safety, health issues, chemical processing control, agriculture and medical applications. This is much important for mine workers. Recently, metal oxide gas sensors by nanostructures have stirred interest and have found their way in many applications due to their high sensitivity, material design compliances and high safety properties. It is indicated that nanoparticles formation on the film surfaces, grain sizes, gas types and operating temperatures have a severe effect on the chemisorption and physisorption process.
\end{abstract}

Keywords: Gas sensors; Types of sensors; Chemical Sensors; Metal oxide sensors.

Received: 14 January 2021; Accepted date: 8 March 2021.

Article type: Review article.

\section{Introduction}

Nature has endowed human and mammalian animals with five primary sense organs namely eyes, ears, tongues, skin and nose. Today there are cameras that mimic the eyes other electronic sensors which mimic tongue, skin and nose..$^{[1-4]} \mathrm{A}$ typical human nose has 400 types of scent receptors enabling us to smell about 1 trillion different odours. In spite of this many times we cannot properly identify the particular gas or concentration of gases present in atmosphere. Here the real need of a sensor.

Today's scientific development has created camera that can mimic eye and there are tactile sensors which can mimic skin. These sensors perform important task of sensing chemical analytes and also giving information of the concentration of analyte in the environment. The industrial revolution tremendously increased the need of fuels. The fossil fuel used during the industrial revolution that still is vital to us even in the present day is coal. Coal has to be mined from the ground, and since mining was primitive, it requires lot of manual labor Coal mining is dangerous occupation. People working in these areas ranged from very young boys to much older man. Thus the start of industrial revolution, the acceleration of coal and mine quarries caused a significant increase in the death of

\footnotetext{
I School of Nanoscience and Technology, Shivaji University, Kolhapur, India.

${ }^{2}$ Department of Physics, Shivaji University, Kolhapur, India.

${ }^{3}$ DKTE College of Engineering, Ichalkaranji, India.

*Email: neeraj_prasad21@rediffmail.com (N. Prasad)
}

mine labors due to toxic gas. Firstly, canaries were used for gas detection in mines. The mines wore flame lights on their helmet so they could see in the tunnels and used hand tools to drill the coal out of the linings of the tunnel. Several things make mining dangerous, chief among them the possible exposure to methane and carbon monoxide. The cost and difficulty of using different methods for determination of toxic gases have revealed the gas sensors.

\section{Need for gas sensors}

The atmosphere we live in is composed of biotic and abiotic factors. In fact, life evolved from abiotic factors. For the perpetuation of life on the planet adequate level of the abiotic factor is quite essential. The abiotic factor includes various types of gases, moisture, humidity, temperature etc. The vital gases like oxygen should be maintained at an adequate level whereas the concentration of hazardous gases should not increase beyond a critical level. Atmospheric pollution can create a high level of health and life loss within the short span of time. Indian has witnessed the lethal effect of methyl isocyanides leakage from union carbide company during the year 1984. This incidence is popularly known as Bhopal gas tragedy which resulted in the death of about 8000 people and about 500,000 were affected. Increased environmental pollution, urbanization, use of automobile motor vehicle, industrial wastes are the major source for the increase in the concentration of gases above the threshold level. There are several diseases which result from pollution. ${ }^{[5-8]}$ World Health Organization is a global organization related to health care. 
According to one survey, seven million deaths take place due to pollution. ${ }^{[9]}$ The air we breathe is composed of $78 \%$ Nitrogen, $21 \%$ oxygen, $0.9 \%$ argon and $0.035 \%$ carbon dioxide. Six pollutants have been identified as the main source of air pollution. The particulate matter consists of lead and gases like oxides of carbon and oxides of nitrogen. The fuel burning in power plants and transport vehicles produces oxides of nitrogen. This adversely affects human health and surroundings. The health ill effect may include disease like asthma and environmental effect may cause acid rain. Air quality control is the main aspect in the field of environmental monitoring. This is because respiratory organ diseases are mainly ascribed to poor air quality. The major diseases resulting from air pollution are stroke, ischemic heart diseases, lower respiratory infections and lung cancer etc. Gas sensing devices are used to protect plants and personnel from inflammable and toxic gases. As gas can adversely affect human and belongings in three main ways as described below:[10-11]

(1) Some gases are inflammable i.e. they can catch fire at room temperature or slightly above it e.g. methane, butane, propane, LPG, etc.

(2) Toxic: Some gases are toxic. They can cause hazard to human and their belongings due to its toxic nature. E.g. carbon monoxide, hydrogen sulfide, chlorine, methyl isocyanide etc. (3) Asphyxiant: We all need oxygen for metabolic process of respiration. The percentage of oxygen in the air is $20.9 \%$. When oxygen level becomes lower than $19.5 \%$ it is considered as oxygen deficient. When oxygen concentration drops below $16 \%$, it becomes unsuitable for human and animals for respiration. Some gases are having a risk of suffocation. Overexposure of Nitrogen leads to a deficiency of oxygen and suffocation takes place. Therefore, in order to protect from hazardous effects, there is a real need for the development of suitable sensing devices.

The impact domain of sensors cannot be restricted merely to some kind of technical sensing organs. Sensors can be used in many other fields. According to Jacob Franden "A sensor is a device that receives signals or stimuli and responds in an electrical signal". It can be alternatively defined as "A device that responds to physical stimulus such as heat, light, sound, pressure, magnetism etc. and transmits a resulting impulse' The working nature of a sensor can be summarized as below: * Sensor should be in direct contact with the investigated subject.

* Sensor should transform non-electrical information into an electrical signal.

* Sensors should respond immediately to external stimuli.

* Sensors should be small in size and cost-effective.

* Sensors should operate continuously or at least in repeated number of cycles.

* The sensors should be specific and selective in nature.

* Sensors should be sensitive i.e. with small amount of analyte it should respond quickly.

In the first time, the toxic gases could be detected by human. Here the person would wear a wet blanket over his shoulder and head and carried a long wick with its end lit on fire. Then the person would enter in mine and begun to move the flame of the wick along the wall of the mine. When the man would hit a small pocket of methane gas, it would ignite, but the miner remained fairly safe under the damped blanket. Coal is the most plentiful fuel derived from fossils. The history of coal used use for heating is at the time of caveman. The depth and darkness of coal mine is the unique dangerous working place. Mine workers may die due to presence of toxic gases such as methane, carbon dioxide, hydrogen sulfide and carbon monoxide. Carbon monoxide is poisonous gas. Carbon monoxide is extremely flammable and is lighter than air thus more dangerous. Thus in 18th century, the presence of poisonous gases were detected with various hit or miss methods. Sometimes canaries i.e. singing birds (Serinus canaria) were used to detect poisonous gases especially carbon monoxide. Male canary sings all the time when they are alone in hope of their song attracting a female. In fact, the main reason for them being held in captivity is their incessant song. When the canaries are kept in mine containing poisonous gases the heartbeat of canaries increases in presence of carbon monoxide. Thus in presence of carbon monoxide the bird stops singing or perhaps could not survive. This was the indication for the presence of poisonous gas especially carbon monoxide. In 1815, British scientist H. Davy developed a gas meter called Davys lamp against methane gas. In 1926, Johnson produced first commercial catalytic combustion gas sensor, and in 1929, the company they founded with Williams became the first company in Silicon valley in electronics. The term sensor became popular during 1970s. At the beginning of 1970 Taniguchi fabricated and patented the first chemoresistive gas sensor device for practical applications using tin oxide as gas sensitive materials. Indeed, after investigating many metal oxides he found that $\mathrm{SnO}_{2}$ has many advantageous properties such as higher sensitivity, low operating temperature and thermal stable structure. In any sensor physical change contributes a chemical change that generates an electric impulse which then drives a circuit. As the name suggests it is a device that senses something or made to sense something. This something is the parameter specific for which it is designed like temperature, pressure, motion, moisture, heat, light or any one of a great number of environmental phenomena. Sensors have the processing unit which read that parameter and convert it to desired readable form. A sensor needs low power to operate. Mode of power for sensor may be active or passive. Active means AC supply and passive means battery with limited life. A sensor is basically a transducer. The sensor reads data in its own way and to understand what the sensor has read we need to convert. It converts the data which is read, into another form of data. Like into voltage, current etc. which can be interpreted by another device and hence we can find the readings. A transducer has the following elements.

Sensors, transducers, signal conditioner, read out. The characteristic of sensor can be divided into two viz static and 
dynamic groups. It is very important to understand these characteristic behaviors to map correctly the relation between the output versus input of the measured. Actually sensor is transducer whose purpose is to detect some characteristic of its environment. It detects events or changes in quantities and provides a corresponding output generally as an electrical or optical signal for example thermocouple. Rapid advances in microelectronics made available technical intelligence. The machines became more intelligent and more autonomous. Therefore, there was a need for development of artificial sensing organs which would enable machines to orient themselves independently. Gas sensors are used to detect combustible, explosive and toxic gases, when the measured gas concentration exceeds the threshold value they can give an alarm that can be used as portable or fixed devices. Nowadays, sensors are widely use in daily life e.g. blood pressure sensor, blood sugar sensors, blood oxygen sensors, blood components sensors, light sensors, taste sensor also known as electronic tongue etc. Even the major laboratory scale analysis needs various types of sensors. But among all types of sensors gas sensing devices are widely used. Actually, it is a component used to detect fluctuation in gaseous state. There are so many gas sensors based upon the elements they sense; some are given below:

(1) Carbon di oxide sensors: used for detection of pollution caused by vehicle emitting $\mathrm{CO}_{2}$.

(2) Alcohol sensors: In fact, alcohol is in liquid state. But the sensor can detect the smell of alcohol. This is widely used by traffic police.

(3) LPG Sensors: It is used for avoiding the destruction caused by leaked LPG cylinders.

The major characteristic of a sensor may be to operate continuously or at least in repeated cycle, respond quickly, transform non-electric information into electrical signals, and be in direct contact with the investigated material and be a small in size. The most important characteristics of a good sensor are stability, sensitivity, repeatability. Generally, sensor is useful when all the three components are tightly specified. There are some additions characteristic which are desired in a good sensor such as selectivity and linearity. A gas sensor is generally a sensor based upon piezoelectric effect and quartz or topaz crystals are studied for change in electrical and vibrational axis. The change in mass axis will be visible in other axis and accordingly correlated. Such sensors are already used by armed forces for gas detection. Gas sensors respond to gas stimuli and changes such as resistance need to be transduced into some meaningful format. The gas sensors are in general non-specific to stimulus and may show changes to many gases. That is why they are used in array conforming with biological olfactory system.

Today there is a great deal of interest in the development of gas sensors for application of air pollution monitoring, detection of harmful gases in mines, grading of agro-products like coffee and spices, home safety, exhaust gas monitoring, hand held breadth analyzer etc. In fact, the gas molecule of interest interacts or gets adsorbed onto the surface of a gas sensitive material and thus induces a change in the electrical characteristic of the material, which is the measure of the gas concentration.

\section{Characteristics of a sensor}

In general, the detectors should present high sensitivity, selectivity, fast reversible response and long term stability. Among the various sensors, semiconducting oxide gas sensors are widely used because of their various advantages over the other gas ${ }^{[10-14]}$ such as:

(1) Sensitivity: The material should show high sensitivity in terms of the variation of resistance or capacitance on contact with a very small quantity of the gas or vapour concerned.

(2) Selectivity: Some materials (e.g. Pt supported on TiO2) are equally sensitive to many gases. This is not a desirable characteristic. Selectivity is an important criterion.

(3) Reproducibility; The material should sense the gas over a large number of cycles extended periods and the sensors should not undergo 8 environmental degradation rapidly due to humidity, temperature and other factors; repeatability.

(4) Cost effective: As for as possible, the sensor should not employ expensive materials such as noble metals because it has to become a consumer product.

(5) Low operating temperature: The operating temperature should be as low as possible the device should not consume more power. This will help in keeping the cost low.

(6) Low response time: The response time as well as the recovery time should be as show as possible.

(7) The size of the final sensor should be as small as possible so that it can be integrate into the circuit easily.

(8) Being a consumer item, it has to be robust and rugged.

(9) Error The difference between the true value of the measuring and the value of the measured by the sensor is known as the error of the sensor.

(10) Resolution signifies the smallest incremental change in the measurand that will detect in an output signal.

(11) Noise If we are not changing the measurand, but some fluctuations occur in the output is known as noise of the sensor. Ambient temperature, electromagnetic waves and mechanical vibrations are some examples of noise.

(12) Stability of the sensor is very important. The stability of a sensor is to produce the same output values for the same inputs for some interval of time.

(13) Response Time The time taken by a sensor to arrive at a stable value is the response time. It is generally expressed as the time at which the output reaches a certain percentage (for instance $95 \%$ ) of its final value, in response to a stepped change of the input. The recovery time is defined in a similar way but conversely.

(14) Hysteresis It is the difference between output readings for the same measurand, when approached while increasing from the minimum value and the other while decreasing from the peak value. 


\subsection{Chemical sensors}

Chemical sensors as a special variety of sensors analyze our environment i.e. they detect which substances are present and in what proportion. God has gifted five sense organs to us. With the help of these sense organs we can see, hear, smell and taste. Thus chemical sensors can be considered as artificial noses or artificial tongues.

The flow chart shown above indicates the similarities between biological and technical systems. In living system, sensory receptor receives the signal from the surrounding. In the same manner in mechanical systems there are sensory receptors. In the transducers the primary information is transformed into electrical signals. In advanced sensor systems, there is additional part for the amplification or conditioning of the signals. At the end of the system, there is microprocessor which can be regarded as central nervous system. The metal oxide nanomaterials exhibiting active response to gas molecules are shown in Table 1.

Table 1. Gas Sensitive Materials and Gas Molecules.

\begin{tabular}{|c|c|}
\hline Materials & Gas/Vapour \\
\hline $\mathrm{SnO}_{2}$ & $\begin{array}{l}\mathrm{H}_{2}, \mathrm{CO}, \mathrm{O}_{2}, \mathrm{NH}_{3}, \text { AsHs, } \mathrm{NO}, \\
\mathrm{NO}_{2} \text {, Ethanol, Hydrocarbons }\end{array}$ \\
\hline $\mathrm{ZnO}$ & $\begin{array}{c}\mathrm{H}_{2}, \mathrm{CO}, \mathrm{O}_{2}, \mathrm{NO}, \mathrm{NH}_{3}, \mathrm{NO}_{2}, \\
\text { Ethanol, and Hydrocarbons }\end{array}$ \\
\hline $\mathrm{Fe}_{2} \mathrm{O}_{3}$ & $\begin{array}{c}\mathrm{H}_{2}, \mathrm{CO}, \mathrm{PH}_{3}, \text { Ethanol and } \\
\text { Hydrocarbons }\end{array}$ \\
\hline $\mathrm{TiO}_{2}$ & $\begin{array}{c}\mathrm{H}_{2}, \mathrm{CO}, \mathrm{CO}_{2}, \mathrm{NH}_{3} \text {, and } \\
\text { Trimethyl amine }\end{array}$ \\
\hline $\mathrm{Cr}_{2} \mathrm{O}_{3}$ & $\mathrm{PH}_{3}, \mathrm{NO}, \mathrm{NO}_{2}$ and $\mathrm{CO}$ \\
\hline $\mathrm{CuO}$ & $\mathrm{H}_{2}, \mathrm{CO}, \mathrm{LPG}$, Ethanol \\
\hline $\mathrm{CeO}_{3}$ & $\mathrm{O}_{2}$ \\
\hline $\mathrm{WO}_{3}$ & $\mathrm{H}_{2} \mathrm{~S}$, Hydrocarbon \\
\hline $\mathrm{V}_{2} \mathrm{O}_{5}$ & $\mathrm{NO}, \mathrm{NO}_{2}, \mathrm{CO}$ and $\mathrm{CO}_{2}$ \\
\hline $\mathrm{Nb}_{2} \mathrm{O}_{5}$ & $\mathrm{NO}, \mathrm{NO}_{2}, \mathrm{CO}$ and $\mathrm{CO}_{2}$ \\
\hline
\end{tabular}

The chemical sensor is well defined by IUPAC in 1991. "A chemical sensor is the device that transforms chemical information ranging from concentration of a specific sample component to total composition analysis into an analytical useful signal." According to Wolfbeis "Chemical sensors can small sized devices comprising the reorganization element and a signal processor capable of continuously and reversibly reporting a chemical concentration." Here the term reversibility indicates that the chemical sensor should not freeze but should response dynamically to the change in sample concentration in the course of measurement. According to Gopel and Schierbaum "Chemical sensors are devices which convert the chemical state into an electrical signal." A chemical sensor is very much analogous to natural sensors present inside animal body. A flowchart is shown in Fig. 1, which representing artificial sensors and natural sensors inside animal body.

\subsection{Some properties of chemical sensors:}

- They are small in size.

- The sensitive layer is in contact with the analyte.

- The chemistry of sensitive layer changes with the exposure of analyte.

- The sensitive layer is on a platform that allows transduction of the charge into electrical signals.

- They operate in real time.

- They are typically less expensive and more convenient than an equivalent instrument for the same chemical measurements.

A chemical sensor essentially contains two basic functional units namely a receptor part and a transducer part. Some sensors may contain a separator e.g. membrane. In the receptors part of a sensor which is a chemical interface, the analyte interacts with chemically with a surface, producing a change in physical/chemical properties. A transducer is the device which can transform the energy carrying the chemical information about the sample into an useful analytical signal. The receptor part of the chemical sensor may be based on principles as below:

Physical: Here no chemical reaction takes place. e.g. Measurement of absorbance, refractive index, conductivity temperature, optical activity, contact angle, mass, etc.

Chemical: - Here some chemical reaction takes place. The analyte chemically react with receptor and gives rise to analytical signal.

Biochemical: - Here biochemical process is the source of analytical signal. e.g. Microbial potentiometric sensors or immune sensors. Such sensors are called biosensors.

Gas sensor is a device which measure and indicate the concentration of certain gases in air. There are various technologies used for gas sensing. The gas sensors are useful to prevent exposure of toxic gases and fire. The gas detectors are battery operated devices used for safety purpose. There are portable gas sensors available in the market. These gas sensors are capable to alert us if the concentration of a particular gas is above permissible limits. These sensors can alert us through a series of audible and visible indicators such as alarms, light or combination of signals. In the earlier stage, the gas detectors were fabricated so as to detect a single gas. But with the advancement of technologies now modern gas detectors are multifunctional and can detect several gases at a time.

Depending upon operating principle gas sensors can be classified as under semiconductor gas sensors, MOSFET sensors, Schottky Barrier sensors, fiber Optic sensors and surface acoustic wave sensors.

\section{Classification of sensors based upon various technology} Sensors can be classified in number of ways. The sensors can be classified into different categories based upon transduction principle. The most commonly used gas sensors can be classified into following three types viz. optical sensors, spectroscopic sensors and solid sensors. 


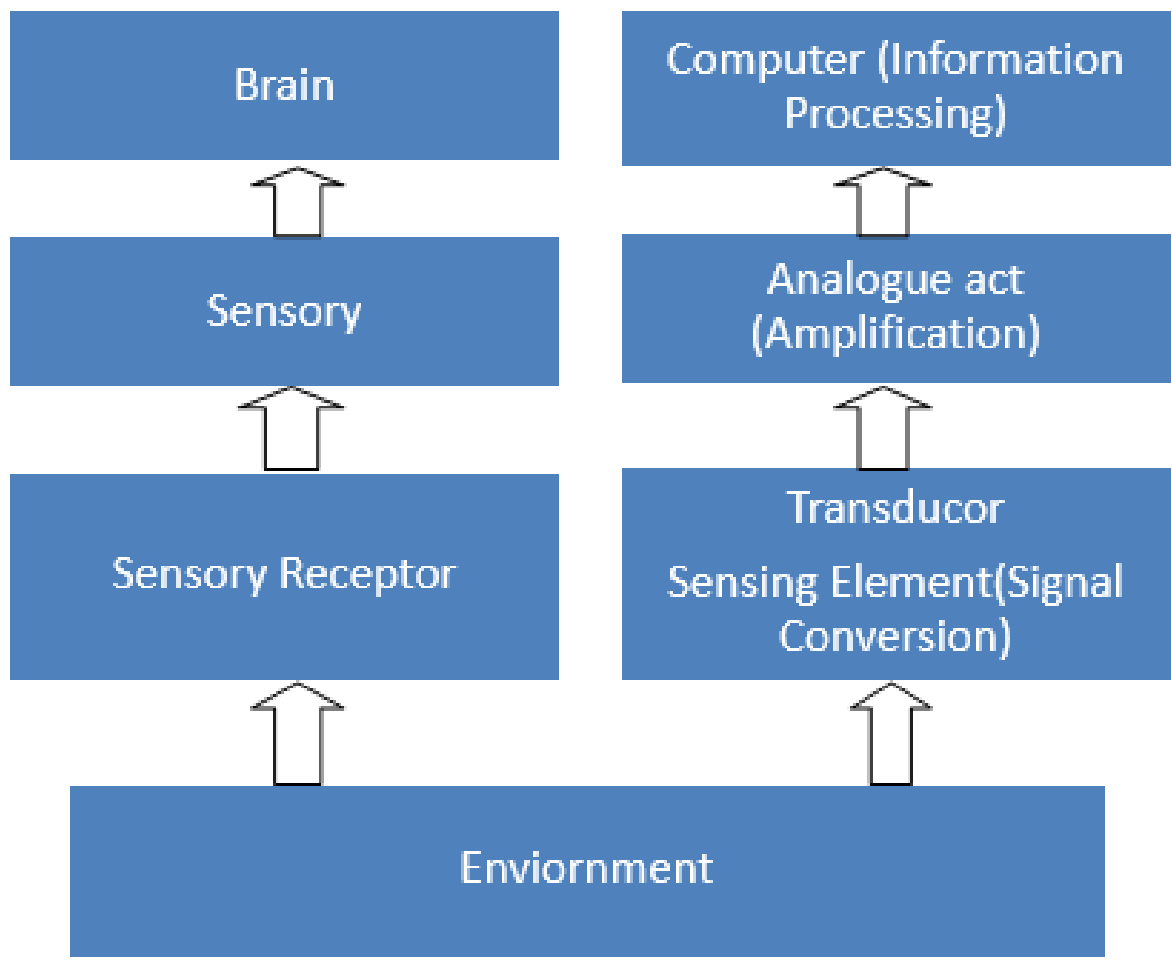

Fig. 1 Flow chart analogous to biological and technical systems.

\subsection{Optical sensors}

Measures absorption spectra after the target gas has been stimulated by electromagnetic radiations of light. This type of sensors uses optical absorption/emission scattering of a gas species at defined optical wavelengths. An optical gas sensor consists of a light emitting element, a photo detecting element, a gas sensing element, the gas sensing element responding to light and a filter for picking up fluorescence or phosphorescence Most optical sensors are usually based on thin films of palladium or chemochromic oxides coated along the length of an optical fiber. This type of fiber optic sensors is known as optodes. As shown by many authors, optical sensors have been used for many years in the detection of flammable gases like hydrogen. The first optical hydrogen gas sensor was reported by Butler in 1984 which consists of an optical fiber with Palladium and Titanium coatings. Detection of hydrogen was made using interferometry. Crawford Massie et al. also designed a low-cost portable optical sensor for methane detection with very good sensitivity, the sensor can operate even in harsh environments. L. N Acquaroli et al. designed an optical porous silicon gas sensor. The system was tested over a detection area of the porous silicon microcavity with isopropyl alcohol vapor and even small changes in concentrations were detected. H. Manap et al. developed an optical fiber sensor for the monitoring of ammonia gas using an open optical path technique. Cross sensitivity of $\mathrm{CO}_{2}$ and $\mathrm{O}_{2}$ was also tested to see their effect on ammonia gas. S. Okazaki et al. also developed a fiber optic hydrogen gas sensor using catalyst-supported tungsten trioxide. The sensor used platinic acid at $500{ }^{\circ} \mathrm{C}$ and showed good response towards hydrogen gas detection and can detect gas even at room temperature. M. Girschikofsky et al. has reported an optical planar Bragg grating sensor which is capable of detecting substances like benzene, toluene and xylene. Results obtained showed good sensitivity towards these gases.

\subsection{Infrared gas sensor}

Infrared sensors consist of a detector which converts electromagnetic radiation energy into electrical signals. The Detectors are of different types namely: Thermoelectric, Thermistor Bolometer, Pyroelectric detector and Photon detector. It also consists of an infrared source which could be a regular incandescent light or a heated wire filament which can be used for the detection of $\mathrm{CO}_{2}, \mathrm{CO}$ and other hydrocarbons. Another component is an optical fiber which could be of two types: dispersive and non-dispersive. Nondispersive types use discrete optical band pass filters and are mostly used for gas sensor applications while the dispersive types use an optical device like a grating or prism. The last but not the least is the gas cell which allows the light path so as to interact with the target gas. Infrared gas sensors are used for detecting different gases like methane, ethane, propane, butane, benzene toluene, xylene and other alcohols like methanol, ethanol etc. H. Okajima et al. developed an Infrared gas sensor using LED for the measurement of methane, absorption of gas samples between 0-97\% were successfully measured, D. Garcia Romeo et al. developed a NonDispersive Infrared (NDIR) gas sensor for the measurement of $\mathrm{CO}_{2}$ gas concentration for wireless sensor networks with low power consumption Similarly Dong Chen et al. designed a tunable diode laser absorption spectroscopy for the measurement of hydrogen sulfide gas. In order to produce a 
sensor that is miniaturized, Guangjun Zhang et al. developed a miniaturized $\mathrm{CO}_{2}$ sensor based on infrared absorption. There are two types of optical structure which is used for the construction of infrared $\mathrm{CO}_{2}$ gas sensors namely: time-double beam and space-double beams. The time-double beam optical structure has only one infrared beam emitted from the infrared source and the detector receives 2 infrared beams with different wavelengths and at different times while the space double beam structure has one infrared beam emitted from the infrared source and simultaneously enters two parallel plate detectors. In this design, the space double beam is used so as to enhance the construction and a cone-shaped air chamber is designed. The optical probe consists of an infrared source, an air chamber, an infrared receiving device and two sapphire windows. The sensor showed an accuracy of $0.026 \%$ with $\mathrm{CO}_{2}$ gas concentration in the range of $0-3 \%$. Naoya Kasai et $a l$. investigated the ability of a system using a carbon infrared emitter and an Infrared camera to detect a combustible gas propane.

\subsection{Spectroscopic techniques}

Spectroscopic analysis mainly involves techniques based on absorption and emission spectra. The principal of absorption spectrometry is the concentration dependent absorption of photons at specific gas concentration.

Apart from the basic method according to prior principles, there are many types of improve absorption spectrometry includes likes Differential optical absorption spectroscopy, Tunable Diode Laser absorption spectroscopy, Raman Light Detection and Ranging and Infra cavity Absorption Spectroscopy.

The Law of emission spectroscopy is that excited atoms will emit photons and then go back to the ground state. Spectroscopic and optical systems are much expensive for domestic applications and sometimes required much space so that cannot be adjusted in small motors vehicles like car etc.

Therefore, there was increasing demand for the sensors which have fast sensing response simple implementation and low price. As they are small in size, they are potable, low power consuming devices and are inexpensive because of considerable production of semiconductor materials.

Especially mass spectroscopic technique makes a direct measurement of molecular mass or vibrational spectra of the target gas. It is possible that the spectroscopic techniques can quantitatively measure the concentration of the components under study. Gas chromatography and mass spectroscopy are the most important spectroscopic gas sensor systems. The spectroscopic and optic systems are too expensive for domestic use and sometimes difficult to implement in reduced spaces such as car engines. Therefore, the solid state sensors are having great advantage its charming qualities such as low cost, simple implementation and fast sensing response. The solid state sensors are small and so they are potable and have low power consuming properties. The gas sensors can be classified into different categories based upon transduction principle. The transducer, converts physical parameters into electrical parameters such as resistance, capacitance and inductance. It provides a sensing voltage or current signal which magnitude, frequency and phase can be measured. Thus in electrically transduced chemical sensors where gas molecules directly interacts with the sensing material these interfaces play a key role in defining the sensitivity, stability and bio-compatibility of sensing devices. The sensing material need to be designed in such a way that it should have large surface area available for interaction with gas molecules. The sensors based upon transduction principle I shown in Table 2 .

Table 2. Sensors based upon transduction principle.

\begin{tabular}{|c|c|c|c|}
\hline $\begin{array}{l}\text { Sr. } \\
\text { No. }\end{array}$ & $\begin{array}{c}\text { Sensor } \\
\text { Classification } \\
\end{array}$ & Transduction Principle & Ref. \\
\hline 1. & Optical & $\begin{array}{l}\text { Absorbance, } \\
\text { Photoluminescence, } \\
\text { Fluorescence, Refractive } \\
\text { Index, optothermal effect } \\
\text { and light scattering }\end{array}$ & {$[12,13]$} \\
\hline 2. & Electrochemical & $\begin{array}{l}\text { Voltometric and } \\
\text { Potentiometric devices, } \\
\text { chemically sensitized field } \\
\text { effect transistor and } \\
\text { potentiometric solid } \\
\text { electrolyte gas sensor. }\end{array}$ & {$[14,15]$} \\
\hline 3. & Electrical & $\begin{array}{l}\text { Metal oxide and organic } \\
\text { semiconductors, } \\
\text { electrolytic conductivity } \\
\text { and electric permecibility }\end{array}$ & [16-18] \\
\hline 4. & Mass sensitive & $\begin{array}{l}\text { Piezoelectric and surface } \\
\text { acoustic waves }\end{array}$ & {$[19,20]$} \\
\hline 5. & Magnetic & $\begin{array}{l}\text { Paramagnetic gas } \\
\text { properties }\end{array}$ & {$[21,22]$} \\
\hline 6. & Thermometric & $\begin{array}{l}\text { The measurement of the } \\
\text { heat effect of a specific } \\
\text { chemical reaction or } \\
\text { adsorption which involves } \\
\text { the analyte }\end{array}$ & {$[23,24]$} \\
\hline 7 & Others & $\begin{array}{l}\text { Emission or absorption } \\
\text { radiation }\end{array}$ & {$[25,26]$} \\
\hline
\end{tabular}

\subsection{Conducting polymers}

Polymers are long chain like molecular structure where repeated molecular units are connected by covalent bonds. Polymers are divided on the basis of their mechanical properties and strength into three categories rubber, elastomers, plastic and fibers. There is a class of polymer known as conducting polymer which was developed in late 1970s by Alan Heeger, Dr Hideki Shriakawa and Alan Macdiarmid. Prior to the use of polymers as conducting materials it was widely used as insulator in electronic industries. The polymers in which carbon atoms in the backbone are linked by double bonds have the potential to conduct electricity, especially when a number of such bonds occur in the vicinity of each 
other. The electrons in one of the two bonds of the double bonds are held a little bit less strongly and can get away from the atoms forming bonds. The electrons in the weaker of the two bonds are shared laterally or sidewise while those in the stronger bonds are in head on manner. The electron can leave the atom to which they originally belonged and travel along the length of the polymer chain. The polymer is weakly conducting or semiconducting. It is also possible the polymer to become conducting when a suitable dopant is added into it. When dopant is added the polymer becomes electronically charged. The polymer chain generates charge carriers due to unpaired electrons. The polymer can be doped with iodine, nitronium species or the salts of transition metals. Another commonly used dopant are the compound of arsenic and fluorine. Conducting polymers are also known as intrinsic conducting polymer which includes polymers of aniline, pyrrole. Such conducting polymers can be used as sensing material and is the active site for gas sensing. The conducting polymers as gas sensing material exhibits many superior qualities over other sensors such as room temperature operation, good mechanical properties and simple cost effective route of synthesis. The main disadvantage for commercial availability of the polymer is the long-term instability and irreversibility and low selectivity among the gases to be detected. When the polymer is doped then its conductivity increases and stability decreases. The polypyrrole can be used to detect $\mathrm{NO}_{2}$ and $\mathrm{NH}_{3}$ gases. It is possible to disperse carbon black in conducting polymers. These are commercially available form of sensors and can be produced with high humidity tolerance. ${ }^{[27-29]}$

\subsubsection{Mechanism of conduction}

It is generally believed that the mechanism of conductivity in the polymers is based on motion of charged defects within the conjugated framework. The charge carrier either positive or negative are product of oxidizing or reducing the polymers. Research on conducting polymers has given the sight for rapid development of molecular electronics. In future scientist may be able to produce transistors and electronic components consisting of individual molecules dramatically increasing the speed and reducing the size of computers.

\subsection{Carbon based materials}

In 1991, during his experiment of electric arc discharge for fullerene production Iijima noticed that certain novel structure also produced which were named afterwards as carbon nanotubes. They are actually graphene sheets rolled specifically in the tube shape. Depending upon diameter carbon nanotubes can be classified as single walled carbon nanotubes and multi walled carbon nanotubes. Studies on applying carbon nanotubes as gas sensing material started about two decades ago. Representing seamless cylinders formed by wrapping of graphene sheets It has been demonstrated that the electronic properties of semiconducting CNTs are very sensitive to certain gas exposure. However, the range of molecules that can be detected by CNTs sensors is limited to the molecules that have large binding energies and charge transfer with the nanotubes. Gas molecules such as toxic gases, water cannot be detected as they do not get adsorbed on the surface of nanotubes. The advancement has led to the development of by substitutional doping of impurity atoms especially atoms of trivalent impurity such as nitrogen and boron. Nanocarbon based materials have proved to be promising candidate for gas sensor applications due to their intrinsic electrical properties that are highly sensitive to their electrical environment. Carbon nanotubes have been employed as gas sensing materials. Graphene materials are used as sensing material because of their specific surface area and unique electrical properties and low noise. High surface area and hollow structure of the nanomaterials have been exposed effective adsorption. Single wall carbon nanotube (SWCNT) A single-walled carbon nanotube can be considered as being formed by rolling a sheet of graphene to create a seamless cylinder with diameters of $0.4-2 \mathrm{~nm}$. Multi wall carbon nanotube (MWCNT) A multi-walled carbon nano tubes comprise of several layers of graphene cylinders that are concentrically nested like rings of a tree trunk, with an interlayer distance close to that of graphite $(0.34 \mathrm{~nm})$. The inner and outer diameter in MWCNT varies from 2 to $30 \mathrm{~nm}$. Both MWCNTs and SWCNTs have diameters in the range between fractions of nanometers and tens of nanometers and length up to several centimeters with both their ends normally capped by fullerene-like structures. Three main methods being developed for CNTs synthesis are arc-discharge, laser ablation, and chemical vapor deposition (CVD). Since the discovery of MWCNTs in 1991 and the SWCNTs in 1993, CNTs have attracted extensive research interest due to their outstanding structural, electronic, and mechanical properties such as unique tubular structure like fullerene, high chemical and thermal stability, low weight, high electrical conductivity, stability, good heat conductance, large surface area, flexibility, high elasticity, and, high mechanical strength. Different types of CNT. The property of SWCNTs is determined by their size and chirality's. The SWCNTs can be metallic or semi conducting. The conductivity of each layer of MWCNTs behaves like an SWCNT along the axial direction, while it is very poor between the layers. As a whole, most MWCNTs display good conductivity. The unique electronic property combining with mechanical property makes carbon nanotubes ideal building. block for electronic devices such as sensors, quantum wires, diodes and field-effect transistors (FETs). The change in electrical properties of CNT when exposed to gas molecules is attributed to charge transfer between the nanotubes and molecules. The preparation process and technique have a significant influence on sensor behavior and properties, so variation can be crucial for the stability of device based on carbon nanotubes. Further, carbon nanotubes gas sensor is slow response and recovery due to the nature of the processes of gas adsorption and desorption by this material. ${ }^{[30,31]}$ 
Table 3. Transition metal sulfide sensors.

\begin{tabular}{lllll}
\hline Crystal structure & Electrical conductivity & Bandgap & Fabrication method & Applications \\
\hline SnS orthorhombic & p-type & Indirect 1.1 & PVD & Photodetectors, gas sensors \\
GaS hexagonal & Semiconductor & Indirect 2.52 & LPE & Hydrogen evolution reaction \\
GeS orthorhombic & p-type & Monolayer indirect 2.34 & Vapour Deposition & High electron mobility \\
ZnS hexagonal & n-type & Direct 3.7 & Hydrothermal & Gas sensing, optical sensors \\
CdS hexagonal & n-type & Direct 2.42 & Spray pyrolysis & Solar cells, gas sensing \\
CuS hexagonal & p-type & Direct 2.5 & Deposition & Solar cells, gas sensors \\
PbS Hexagonal & n-type & Bulk $0.373 \mathrm{~nm}$ & Chemical Bath Deposition & Solar cells, photonics, gas sensors \\
NiS Rhombohydral & p-type & 0.5 & Solvothermal & Photo catalyst \\
\hline
\end{tabular}

\subsection{Catalytic sensors}

Many times metal oxide gas sensing devices require a suitable catalyst deposited on the surface of a semiconductor. The deposited catalyst enhances the rate of chemical reaction and increases the sensitivity. A catalyst is foreign material that alters the rate of a chemical reaction without taking actual part in the course of reaction. A catalyst does not change the free energy of reaction but it can lower the energy of activation. The catalyst or promoters are chosen so as to influence the selectivity of a sensor device. Ideally a particular catalyst should enhance the oxidation of a specific gas alone without affecting another gas. But number of time along with the oxidation of gases under study, the catalyst can catalyze the oxidation of another gas also. Most hazardous gas can be oxidized with release of heat. Therefore, an accurate measurement of these gases can be achieved using catalytic sensors. This sensor detects gas based on heat generated by combustible gas burning on oxidation catalyst. It is the most widely used gas sensor designed specifically for combustion gases.

As in chemical reaction, catalyst plays important role for semiconducting gas sensing devices also. In fact, one should think that catalyst should not affect gas sensing or rather lower the gas sensing activity. Detection of various kinds of gases via the enhancement of the sensor response and a decrease of operating temperature of sensor response. It is also reported that certain additives can decrease in response time.

Since the pioneering work by Shaver and Loh, the promoting effect of noble metals have been confirmed in many semiconductor gas sensors. $\mathrm{TiO}_{2}$ based sensors can be promoted by the addition of small amount of various metals, such as $\mathrm{Pt}, \mathrm{Pd}, \mathrm{Rh}$ and $\mathrm{Ag}$. It was observed that the addition of metals influences the sensitivity in a rather complex manner depending on the objective gases and operating conditions. As the gas sensitivity usually goes through a maximum when the temperature changes, the maximum sensitivity (SM) and the temperature (TM) for SM are conventionally utilized to characterize the effect of 37 noble metals. It can be said generally that the additional of noble metals result in increase of SM lowering of TM and increase in rate of response. The first and third are important for obtaining high gas sensitivity, while the second is important for optimizing the gas selectivity. From these features, commercial sensors almost always have noble metals added. Noble metals are active catalysts for the catalytic oxidation of hydrocarbons, $\mathrm{CO}$ and $\mathrm{H}_{2}$. In fact, the catalytic activity of $\mathrm{TiO}_{2}$ powder has been shown to increase when impregnated with these metals, and such increase in catalytic activity is a reason for lowering of TM. ${ }^{[32]}$

\subsection{Metal sulfides}

In recent years, metal sulfides have emerged as a class of gas sensing measurement. CdS and $\mathrm{SnS}_{2}$ thick films have been tried for gas sensing applications. These materials showed better sensing properties with their respective metal oxide counterparts. The metal sulfides also exhibit gas sensing properties. The various metal sulfides exhibiting gas sensing properties are shown in Table 3.

\subsection{Semiconductor gas sensing materials}

This sensor used a metal oxide semiconductor which changes in resistance when it comes in contact with detectable gas. The sensor detects this change in resistance as the gas concentration. This is a general purpose sensor that detects all types of gases ranging from toxic gases to combustible gases. Brattain and Bardeen were the first to report on gas sensitive effects on germanium in 1952 making it the first semiconductor used as gas sensitive material. Metal oxide stand out as one of the most common diverse and most likely largest class of materials due to their extensive structural, physical and chemical properties and functionalities. The most common metal oxide utilizes as sensing layer in chemosensative devices are binary oxides of p-block elements and transition metals. Metal oxides are used for making gas sensing devices as they exhibit many advantages. They are simple to operate, low cost and suitable for large number of gases. Actually metal oxides are basically semiconducting in nature. After the various development in semiconducting materials, it was Brattain and Bardeen who first put forward the idea to use metal oxides semiconductors as gas sensing materials. Then another scientist P J Shavar and Seiyaman et $a l$. found the gas sensing behavior of metal oxides. Japanese's 
scientist Mr. Naoyoshi Taguchi is the first person in the world who developed semiconducting devices capable of detecting low concentration of combustible and reducing gases. Thus metal oxide emerged as a class of material useful for gas sensing. The semiconducting metal oxides exhibiting gas sensing properties are porous polycrystalline materials. In case of metal oxide semiconductors, surface of metal oxide grains is involved in receptor function while the grain boundaries act as transducers. The gas diffuses into sensor, through the back of porous membrane. The metal oxide gas sensors possess a wide range of electronic, chemical and physical properties that are highly sensitive to change in their chemical environment.

Here the change in physical properties of the film upon gas exposure is measured. The sensing behavior is the most important and well-known properties of a metal oxide material Semiconductors gas sensors detect gases by chemical reactions that takes place when gases come in contact with the sensor. Zinc oxide and tin dioxide are the most common metal oxides used in gas sensors. The electrical resistance in the sensor is increased when it comes in contact with the monitored gas like $\mathrm{NO}_{2}$. Based upon the electronic structure the gas sensing materials may be of different metal oxides such as $\mathrm{Cr}_{2} \mathrm{O}_{3}, \mathrm{ZnO}, \mathrm{SnO}_{2}, \mathrm{MnO}_{2}, \mathrm{NiO}, \mathrm{GeO}, \mathrm{CuO}, \mathrm{MoO}_{3}$, etc. Thus these metal oxides can be broadly classified into two main types such as transition metal oxide and non-transition metal oxides. Pre-transition metal oxides are rarely used as gas sensing materials for detection of gases. This is because of large band gap observed in s block element metal oxides. Therefore, only transition metal oxides with $\mathrm{d}^{0}$ and $\mathrm{d}^{10}$ configurations are widely used as sensing materials. The earlier members of transition metal series show $\mathrm{d}^{0}$ configuration whereas the lateral members of the series shows $\mathrm{d}^{10}$ configurations. A semiconductor gas sensor is a n-type intrinsic semiconductor. The metal oxide crystals are often loaded with small amount of foreign substance (noble metals or their oxides) called a sensitizer. Doping the metal oxide layer with suitable promoter is a common way of enhancing the sensing characteristic of chemo resistive gas sensors.

\subsubsection{When metal additives are added}

This can lead to two different sensitization mechanisms

(1) Chemical sensitization (spill over mechanism)

(2) Electronic sensitization (Fermi level mechanism).

In first case, the promoting effect is due to the ability of noble metals to activate inflammable gases by enhancing their spill over, so that they react with oxygen adsorb more easily. The promoter in case activates a test gas to facilitate its catalytic oxidation on the semiconductor surface. Thus, the promoter does not affect the resistance of the element directly, leaving the gas sensing mechanism essentially the same as in the case without it. The promoter increases the gas sensitivity as it increases the rate of the chemical process leading to decrease in concentration of the negatively change of adsorbed oxygen. Therefore, the effect is called as chemical sensitization. Thus, the additive exerts a sort of remote control on the catalytic and sensing properties of the metal oxide. In second case, electronic sensitization is associated with oxidized metal oxide. Electronic sensitization comes out through a direct electronic interaction between the promoter and semiconductor surface. When the oxidation state of promoter changes with surrounding atmosphere, the electronic stat of the semiconductor will also change.

It has been observed that addition of fine particles of some metals to n-type metal oxide usually results in a rise of the base resistance of semiconductor metal oxide in air. There is decrease in the electron concentration in the oxide surface layer. Which corresponds to an increase of space charge depth as a result of electron transfer from the metal oxide to metal loaded on to its surface. When the metal surface is converted with oxygen adsorbed at elevated temperature. In air, the oxygen adsorbed extract electrons. As there is tremendous increase in surface area at nano regime, for the same chemical composition, the smaller Nanoparticles are, the more sensitive. The interaction taking place between a gas and a solid mainly taken place on the surface and interfaces are crucial for controlling the properties of the gas sensors. In monocrystalline materials the proportion of atoms at the surface are very high. The doped metal oxide as gas sensing material is shown in Table 4.

When the sensor comes in contact with the monitored gas, the resistor changes its resistance sharply which enables us to know the exact concentration of gas. The conductivity behavior of doped metal oxide semiconductor depends upon its nature of doing viz.

Table 4. Doped metal oxides as gas sensors.

\begin{tabular}{lll}
\hline Type of Material & Oxidizing Gases & Reducing Gases \\
\hline n-type & Resistance increases & Resistance decreases \\
p-type & Resistance decreases & Resistance increases \\
\hline
\end{tabular}

Nano thin films are films of materials, having a thickness within the nanometer range. The thin film consists of transition metal oxides. Many times transition metal oxides are doped with suitable dopants like carbon nanotubes, polymers or some another transition metals. The transition metal oxide can be synthesized by bottom up route of synthesis like atomic layer deposition, hydrothermal route of synthesis etc. Nanotechnology provides many advantages for gas sensing development. Materials at nanoscale consumes lower power for operation, are faster and can detect gases at lower limit. The gas sensing materials at nano level are most resistant to heat shock and are cost effective.

Nowadays semiconductor gas sensors are generally three types such as (1) sintered, (2) thin film and (3) thick film gas sensors. However, in recent years a combination of various semiconductor sensors, an alternating in working temperature and introduction of computer pattern recognition techniques have been tried for solving the long term problem of qualitative and quantitative measurement of mixture of gases. 


\subsubsection{How does a gas sensor work}

When metal oxide is heated on air at high temperature, oxygen is adsorbed on the surface. In clean air, donor electrons in metal oxide are attracted towards oxygen which is absorbed on the surface of the sensing material. This prevents electric current flow. In the surface of reducing gases, the surface density of adsorbed oxygen decreases as it reacts with the reducing gases. Electrons are then released into the metal oxide, allowing current to flow freely through the sensor.

\subsubsection{Working principle}

Depending upon the concentration of the analyte the sensor produces a corresponding potential by changing the resistance of the material inside the sensor, which can be measured as output voltage. Depending upon the output voltage the nature and concentration of the gas can be successfully estimated. The nature of gas to be detected depends upon the nature of sensing materials. Normally these sensors are available as modules with comparators. The metal oxide gas sensor works on chemi-resistance principle. When the gas molecule interacts with metal oxide surface, it acts as either an acceptor or donar. This changes the resistivity or electrical conductivity of thin film. The resistivity of the metal oxide semiconducting thin film depends on majority charge carriers in the film and also gas molecules nature i.e. whether it is oxidized or reduced in the ambient temperature. When the concentration of gas exceeds the threshold value the digital pin goes high. The analog pin can be used to measure the concentration of the gas.

\subsubsection{Gas sensor construction}

Today the most commonly used type of gas sensor is metal oxide-based gas sensor. The metal oxide gas sensor consists of various components such as gas sensing layer, heater coil, electrode line, tubular ceramic and electrode.

\subsubsection{Advantages of semiconductor sensors}

- Semiconductor gas sensors are comparatively inexpensive to manufacture due to their simplicity and scalability.

- Specific sensors can be designed for particular applications. e.g. a sensor can be designed for low concentration applications where as an alternative sensor can be designed for high concentration applications.

\subsubsection{Limitations of semiconductor sensors:}

- It is possible that non-targeted gas may get adsorbed on metal oxide thin film and give false results.

- The relationship between response and concentration may not be linear. Individual calibration of sensors may be necessary which can lead to increasing sensors cost associate with resources and labor time.

- Semiconductor sensors can be unreliable at high relative humility and varying temperature.

\subsection{Solid state gas sensing devices}

At the early stage of development of semiconductors, scientist noticed that $p-n$ junctions were sensitive to sensitive to environmental background gases. Initially this was looked as a problem and it was solved by encapsulating the semiconductor chip so that it was no longer exposed to outside environment. After that, number of efforts was made to utilize the sensitivity of a semiconductor junction as a gas detector. Classification of solid state gas sensor as below in Table 5 .

Table 5. Classification of solid-state gas sensors.

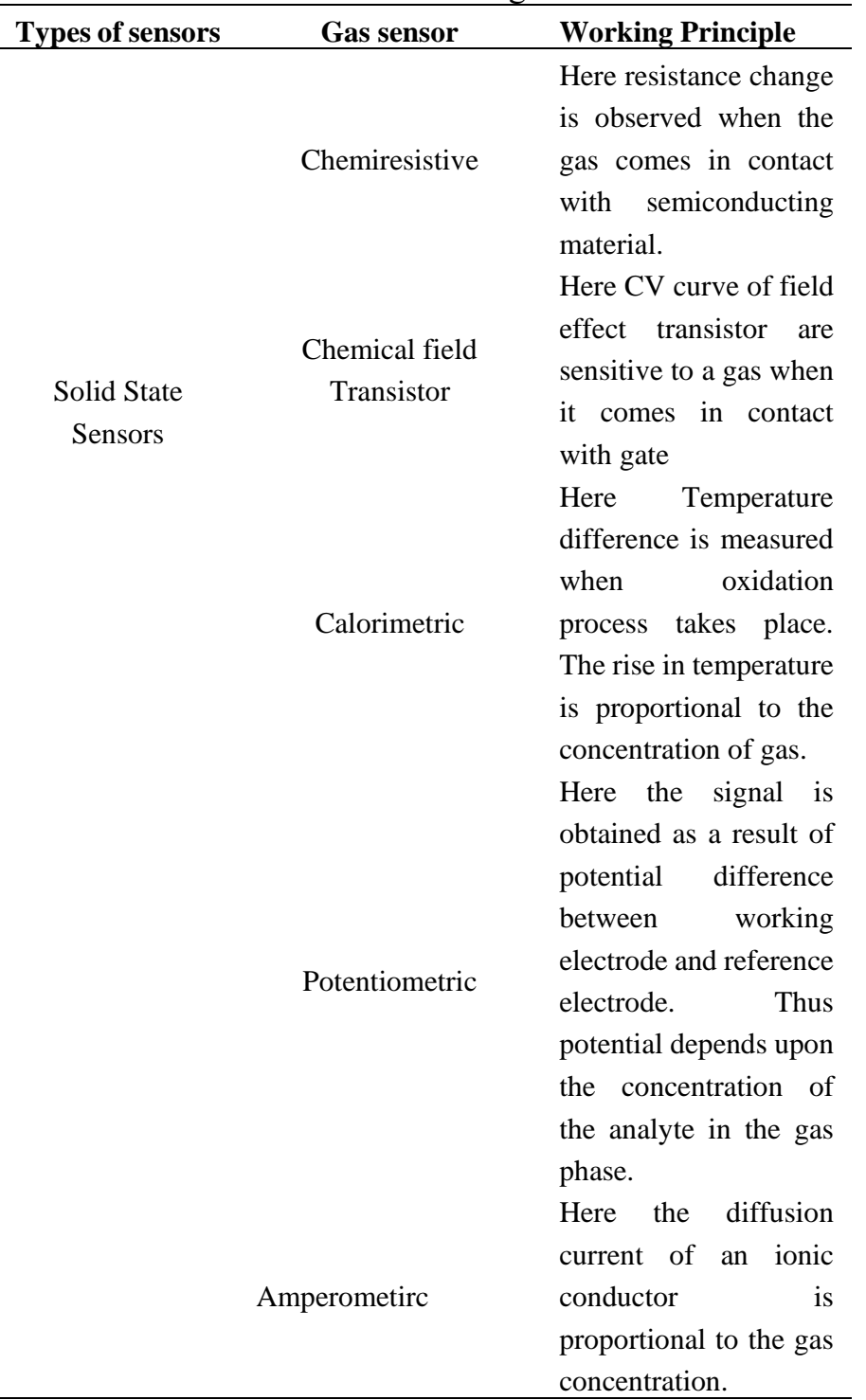

Solid states gas sensing material may be organic or inorganic type materials. These materials are deposited in the form of thin or thick films on a nonconducting substrate like glass slides. Semiconductor based chemiresistor sensors are most investigated and widely used for detection of combustible and toxic gases due to their low cost and relatively simple fabrication techniques.

From the metal, which in turn extracts electrons from metal oxide leading to a further increase in the space charge depth. 
Table 6. Metal oxide chemiresistive materials, additive and the analyzing gas.

\begin{tabular}{|c|c|c|c|c|}
\hline $\begin{array}{c}\text { Metal Oxide } \\
\text { Chemiresistive } \\
\text { materials }\end{array}$ & Additives & Analyzing gases & Descriptions & Refs \\
\hline $\begin{array}{l}\text { Aluminum oxide } \\
\left(\mathrm{Al}_{2} \mathrm{O}_{3}\right)\end{array}$ & & $\begin{array}{l}\text { Humidity } \mathrm{CH}_{4} \text {, } \\
\mathrm{NH}_{3}\end{array}$ & $\begin{array}{l}\text { Porous structure made by electrochemical anodization of aluminum thin } \\
\text { films. } \\
\text { Regeneration by heating above } 100{ }^{\circ} \mathrm{C} \text {; sensor saturated after long } \\
\text { exposure to humidity. } \\
\text { Nanoporous alumina able to operate at room temp. as ammonia sensor }\end{array}$ & [33-36] \\
\hline $\begin{array}{l}\text { Bismuth oxide } \\
\left(\mathrm{Bi}_{2} \mathrm{O}_{3}\right)\end{array}$ & $\mathrm{Sb}_{2} \mathrm{O}_{3}$ & $\begin{array}{l}\text { Smoke sensor }(\mathrm{CO}, \\
\left.\mathrm{CO}_{2}\right), \mathrm{H}_{2} \\
\mathrm{NO} \text { and } \mathrm{O}_{2}\end{array}$ & $\begin{array}{l}\text { Sensitive to many gases. } \\
\text { Operated at high temperature }\left(450^{\circ} \mathrm{C}\right) \text {. Doping with } \mathrm{Sb}_{2} \mathrm{O}_{3} \text { enables the } \\
\text { reduction of operating temperature to } 200 \mathrm{oC} \text {.Additives such as } \mathrm{Fe} \text { and } \mathrm{Ag} \\
\text { stabilize the structure and } \mathrm{Cu} \text { induces high selectivity for NO. }\end{array}$ & [37-39] \\
\hline $\begin{array}{l}\text { Cadmium oxide } \\
(\mathrm{CdO})\end{array}$ & & Additive ethanol & $\begin{array}{l}\text { No gas sensing properties for pure } \mathrm{CdO} \\
\text { By adding to } \mathrm{ZnFe}_{2} \mathrm{O}_{4} \text {, improves the selectivity in detecting ethanol among } \\
\text { a mixture of petrol, } \mathrm{H}_{2}, \mathrm{CO}, \mathrm{LPG} \text {, and other hydrocarbon gases, as well as } \\
\text { stability, durability, and response behavior. }\end{array}$ & [40] \\
\hline Ceria $\left(\mathrm{CeO}_{2}\right)$ & & $\mathrm{O}_{2}, \mathrm{H}_{2} \mathrm{~S}$ & $\begin{array}{l}\text { Oxygen gas sensor due to the chemical stability and high diffusion } \\
\text { coefficient of oxygen vacancies. } \\
\text { By adding to } \mathrm{TiO}_{2} \text { or } \mathrm{SnO}_{2} \text { increases sensitivity to } \\
\mathrm{O}_{2} \text { and } \mathrm{H}_{2} \mathrm{~S} \text {, respectively. }\end{array}$ & {$[41,42]$} \\
\hline $\begin{array}{l}\text { Chromium oxide } \\
\left(\mathrm{Cr}_{2} \mathrm{O}_{3}\right)\end{array}$ & $\mathrm{TiO}_{2}$ & $\begin{array}{l}\mathrm{NO}_{2}, \mathrm{O}_{2} \\
\mathrm{H}_{2}, \mathrm{NH}_{3} \text { and } \\
\text { Humidity }\end{array}$ & Sensitive to $\mathrm{NO}_{2}, \mathrm{O}_{2}$ and humidity, doped by $\mathrm{TiO}_{2}$. & [43-45] \\
\hline $\begin{array}{l}\text { Cobalt oxide } \\
\left(\mathrm{Co}_{3} \mathrm{O}_{4}\right)\end{array}$ & $\mathrm{SiO}_{2}$ & $\begin{array}{l}\mathrm{NH}_{3}, \mathrm{CO}, \mathrm{CH}_{4}, \\
\mathrm{C}_{3} \mathrm{H}_{8}, \\
\mathrm{H}_{2} \text { and } \mathrm{NO}_{2}\end{array}$ & $\begin{array}{l}p \text {-type semiconductor with energy band gap of } 1.4-1.8 \mathrm{eV} \text { induced by non- } \\
\text { stoichiometrically excessive oxygen. } \\
\text { Sensitive to many sorts of gases. } \\
\text { Thin film operates as } \mathrm{NH}_{3} \text { gas sensor even at room temperature. }\end{array}$ & [46-48] \\
\hline $\begin{array}{l}\text { Copper oxide } \\
(\mathrm{CuO})\end{array}$ & $\mathrm{SnO}_{2}$ & $\begin{array}{l}\mathrm{NO}_{2}, \mathrm{CO} \\
\text { and } \mathrm{H}_{2} \mathrm{~S}\end{array}$ & $\begin{array}{l}p \text {-type semiconductor. } \\
\text { Used as an additive to } n \text {-type metal oxide to give improvement or } \\
\text { selectivity. For example, } \mathrm{CuO} \text {-doped } \mathrm{SnO}_{2} \text { is highly sensitive to } \mathrm{H}_{2} \mathrm{~S} \text {. } \\
\text { Also used as a catalytic membrane for } \mathrm{CO} \text { and } \\
\text { ethanol detection }\end{array}$ & [49-52] \\
\hline $\begin{array}{l}\text { Iron oxide } \\
\left(\mathrm{Fe}_{2} \mathrm{O}_{3}\right)\end{array}$ & $\mathrm{Au}, \mathrm{Zn}$ & $\begin{array}{l}\text { Organic gases, } \mathrm{CO} \\
\text { and } \mathrm{NO}_{2}\end{array}$ & $\begin{array}{l}n \text {-type semiconductor; } \alpha \text { - } \mathrm{Fe}_{2} \mathrm{O}_{3} \text { (hematite) has complex defect structures } \\
\text { such as oxygen vacancies, } \mathrm{Fe}^{3+} \text { interstitials and } \mathrm{Fe}^{2+} \text { interstitials, which } \\
\text { induce semiconducting properties. } \\
\text { Transition to } p \text {-type can occur by: the gas concentration, dopants, and the } \\
\text { operating temperature } \\
\text { Many dopants enable } \mathrm{Fe}_{2} \mathrm{O}_{3} \text { to be selective for a particular gas: } \\
\text { - } \mathrm{ZnO}\left(\mathrm{NH}_{3}\right) \text { at room temperature, } \\
\text { - } \mathrm{Pt}, \mathrm{Pd} \text { or } \mathrm{RuO}_{2}(\text { acetone) } \\
\text { - } \mathrm{Au}, \mathrm{Zn}\left(\mathrm{CO} \text { and } \mathrm{NO}_{2}\right)\end{array}$ & [53-56] \\
\hline
\end{tabular}




\begin{tabular}{|c|c|c|c|}
\hline $\begin{array}{l}\text { Gallium oxide } \\
\left(\mathrm{Ga}_{2} \mathrm{O}_{3}\right)\end{array}$ & $\begin{array}{l}\mathrm{SnO}_{2}, \mathrm{Pd}, \\
\mathrm{Ta}_{2} \mathrm{O}_{3}, \mathrm{WO}_{3}, \\
\mathrm{NiO}\end{array}$ & $\begin{array}{l}\mathrm{O}_{2}, \mathrm{CO}, \mathrm{NO}, \mathrm{NH}_{3} \\
\text { and } \mathrm{CH}_{4}\end{array}$ & $\begin{array}{l}\text { Semiconductor with the energy band gap of } 4.9 \mathrm{eV} \text {. Usual operating } \\
\text { temperature is about } 1000{ }^{\circ} \mathrm{C} \text {. Due to the high operating temperature: } \\
\text { - } \quad \text { Low base line is established quickly without drift } \\
\text { - } \quad \text { Not cross-sensitive with humidity } \\
\text { - } \quad \text { Rable even at a low partial pressure of oxygen in atmosphere } \\
\text { - } \\
\text { Doping with } \mathrm{Ta}_{2} \mathrm{O}_{5}, \mathrm{WO}_{3}, \mathrm{NiO} \text { and } \mathrm{SnO}_{2} \text { makes it sensitive to } \mathrm{NO}, \mathrm{NH}_{3} \text {, } \\
\mathrm{CO} \text { and } \mathrm{CH}_{4} \text {. } \\
\text { The operating conditions may be a disadvantage regarding energy } \\
\text { consumption. }\end{array}$ \\
\hline $\begin{array}{l}\text { Indium oxide } \\
\left(\mathrm{In}_{2} \mathrm{O}_{3}\right)\end{array}$ & & $\begin{array}{l}\mathrm{O}_{3}, \mathrm{NO}_{2}, \mathrm{H}_{2}, \mathrm{H}_{2} \mathrm{~S} \\
\mathrm{Cl}_{2}, \mathrm{NH}_{3}, \\
\text { ethanol, acetone }\end{array}$ & $\begin{array}{l}n \text {-type semiconductor with energy band gap of } 3.55-3.75 \mathrm{eV} \\
\text { Highly sensitive for detection of oxidizing gases, } \mathrm{O}_{3} \text { and } \mathrm{NO}_{2} \text {, even at } \\
\text { very low concentration. } \\
\text { Enhanced selectivity for } \mathrm{NO}_{2} \text { by doping with } \mathrm{MoO}_{3} \\
\text { Can detect many toxic gases }\end{array}$ \\
\hline $\begin{array}{l}\text { Molybdenum } \\
\text { Oxide }\end{array}$ & & $\begin{array}{l}\mathrm{NH}_{3} \text { and } \\
\mathrm{NO}_{\mathrm{x}}\end{array}$ & $\begin{array}{l}\text { n-type semiconductor with energy band gap of } 3.2 \mathrm{eV} \text {. The catalytic } \\
\text { properties on oxidation of hydrocarbons and conversion of NOx to } \\
\text { nitrogen are attracting investigation for gas sensing properties. Ti coating } \\
\text { over MoO3 can enhance the sensitivity for NH3. Limited use as a gas } \\
\text { sensor owing to the comparatively low melting temperature }\left(795^{\circ} \mathrm{C}\right) \text {. } \\
\text { Restricted by high resistivity at room temperature }(1010 \Omega \mathrm{cm}) \text { for } \\
\text { utilization as a gas sensor and integration into a circuit. }\end{array}$ \\
\hline $\begin{array}{l}\text { Niobium oxide } \\
\left(\mathrm{Nb}_{2} \mathrm{O}_{5}\right)\end{array}$ & $\mathrm{SnO}_{2}$ & $\mathrm{NH}_{3}$ & $\begin{array}{l}\text { Attractive dielectric material for solid-type electrolytic capacitors due } \\
\text { to its high dielectric } \\
\text { constant and durability. } \\
\text { As n-type semiconductor gas sensor, } \mathrm{Nb}_{2} \mathrm{O}_{5} \text { can } \\
\text { detect } \mathrm{NH}_{3} \text {. }\end{array}$ \\
\hline $\begin{array}{l}\text { Nickel } \\
\text { Oxide } \\
(\mathrm{NiO})\end{array}$ & $\mathrm{Li}, \mathrm{TiO}_{2}$ & $\begin{array}{l}\mathrm{NO}_{2}, \\
\text { Formaldehyde } \mathrm{H}_{2}, \\
\mathrm{CH}_{4} \text { and } \\
\mathrm{CO}\end{array}$ & $\begin{array}{l}p \text {-type semiconductor with energy band gap of } 4.2 \mathrm{eV} \text {. Wide range of } \\
\text { applications due to its good chemical stability, and optical and electrical } \\
\text { properties in supercapacitors, catalysts, electrochromic films, p-type } \\
\text { transparent films and fuel cell electrodes. } \\
\text { Li-doping enhances the selectivity to } \mathrm{H}_{2} \text { or formaldehyde by promoting } \\
\text { oxidation. }\end{array}$ \\
\hline
\end{tabular}

Continued

[57-61]

$\left(\mathrm{In}_{2} \mathrm{O}_{3}\right)$

Titanium oxide $\left(\mathrm{TiO}_{2}\right)$ $\mathrm{WO}_{3}$

$\begin{array}{lll} & & \mathrm{NH}_{3} \text { and } \\ & & \mathrm{NO}_{2} \\ & & \\ \text { Tungsten oxide } & \mathrm{Mg}, \mathrm{Zn}, \mathrm{Mo}, & \mathrm{NH}_{3}, \mathrm{NO}, \\ \left(\mathrm{WO}_{3}\right) & \mathrm{Re}, \mathrm{Au}, \mathrm{Pd} & \mathrm{H}_{2} \mathrm{~S} \text { and } \mathrm{O}_{3}\end{array}$

$n$-type semiconductor with good response to $\mathrm{NH}_{3}$ and $\mathrm{NO}$.

Adsorbed $\mathrm{O}_{2}$ does not cover the surface as it does on $\mathrm{SnO}_{2}$ surface elements, so a catalyst or promoter are required:

- Elements such as $\mathrm{Au}, \mathrm{Mo}, \mathrm{Mg}, \mathrm{Re}$, etc. achieve selectivity for toxic gases.

- $\quad$ Doping with $\mathrm{Cu}$ or surface modification with $\mathrm{Au}$ and Pt enhance sensitivity to $\mathrm{NH}_{3}$. 


\begin{tabular}{|c|c|c|c|}
\hline & & & Continue \\
\hline $\begin{array}{l}\text { Vanadium oxide } \\
\left(\mathrm{V}_{2} \mathrm{O}_{5}\right)\end{array}$ & Additive & $\begin{array}{l}\text { As a catalyst in oxidation reactions, is used as a promoter for gas sensors } \\
\text { by adding to such metal } \\
\text { oxides as } \mathrm{TiO}_{2}, \mathrm{MoO}_{3} \text { and } \mathrm{ZnO} \text {. }\end{array}$ & [106-108] \\
\hline Zinc oxide & & $\begin{array}{l}\text { Highly attractive metal oxide with various } \\
\text { applications in optical, electrical and piezoelectric } \\
\text { areas. } \\
\text { The first metal oxide gas sensing material. Tremendous research has been } \\
\text { done and found many sensing capabilities toward trimethylamine, } \\
\text { hydrogen, oxygen, ethanol and } \mathrm{NH}_{3} \text {, with stability. }\end{array}$ & [109-118] \\
\hline
\end{tabular}

4. Metals oxide semiconductor nanoparticles for chemical gas sensors

Gas adsorption is mainly a surface-related phenomenon. The grain size and area of an active surface layer are the main parameters which control the gas sensing phenomenon in solid-state gas sensing devices. Therefore, the decrease in particle size plays a crucial role in gas sensing phenomenon. Because of high surface, metal oxide Nanoparticles are the suitable candidates for gas sensing devices.

\subsection{Interaction of gaseous species at semiconductor surface} The intrinsic semiconductor gas sensors are of two types i.e. p-type metal oxide gas sensors and n-type metal oxide gas sensors. Although two types of metal oxide semiconductors gas sensors are possible but the majority of the semiconductor gas sensors are of n-type. The pure undoped metal oxide semiconductor can be n-type or p-type depending upon the defects in the crystals. Consider $\mathrm{ZnO}$ semiconductor.

This is the example of the extrinsic semiconductor. However, in the undoped condition of cations are missing the crystalline acquires a negative charge and behaves as n-type semiconductor and vice a versa. As cations are smaller in size, missing of the cation is more common as compared to missing of anions. When a solid is terminated by the surface, the surface atoms are incompletely coordinated-one or two nearest neighbours are missing, and there are dangling bonds. Their dangling bonds are unsatisfied and unshared with neighbours.

\subsection{Device development}

The sensor performance is highly dependent upon design of the sensor device and material. The semiconductor materials used as gas sensing devices need to be heated often in the range of $150-450{ }^{\circ} \mathrm{C}$. In the common type of gas sensing devices the electrode is printed on one side generally on the top of the substrate and heater is printed on the bottom on the substrate. The electrodes and heaters are printed using transition metals such as silver, gold, palladium, platinum while the substrate is made up of silicon dioxide or alumia. In this type of sensing devices there is much more consumption of the energy due to heating of thick substrate. Therefore, researchers were in the search to overcome this problem. This could be successfully overcome using complementary metal oxide semiconductor compatible MEMS fabrication process. MEMS technique requires less power consumptions, high sensitivity and wafer based manufacturing. This technology is easily reproducible and scalable. Semiconductor materials are deposited on MEMS substrate in the form of thick and thin films. The various technologies can be used for formation of thin films.

\subsection{Thin films}

Thin film technology has progressed rapidly in the direction of thin film coating and also have been developed for the need of the industry. It serves a number of purpose for various used including electronics, optical coating, superconducting films magnetic films for data storages, environmental smart windows, heat prevention and corrosion resistance and super hard coating. There is no accurate definition for thin or thick films. In general, if the thickness of film is below $1 \mu \mathrm{m}$ it is considered as thin film. But normally when the solid material is coated on the solid support known as substrate the film developed is called thin film. The thin films are having different properties than thick films. In the present scenario many researchers have developed thin and thick films which can be successfully used as gas sensing devices. Here nanotechnology plays a key role which can rectify and provide huge opportunity to provide next generation gas sensing devices with enhanced sensing performance in terms of fasr response time and selectivity at very low concentration of the analyte. A major attraction of nanomaterials in the gas sensor application is because of high surface area to volume ratio known as aspect ratio. The electrical conductivity of semiconductor gets altered when it comes in contact with gas molecules under study. Nanostructured metal oxide thin film produces very high sensitivity due to high surface activity and unique microstructure. High adsorption of gas species on the surface and subsequent catalytic activity with the adsorbed species enhances sensing performance and thus reducing response time compared to the conventional microstructure gas sensors.

The majority of the sensor work reported so far are based on various metal oxide semiconductors. These materials can be doped easily or sensitized by using suitable transition metal. 
Table 7. Comparative study of advantage and disadvantage of sensors based upon transduction principle.

\begin{tabular}{|c|c|c|c|}
\hline Number & Sensor Type & Advantage & Disadvantage \\
\hline 1 & Optical & $\begin{array}{l}\text { Easy to operate } \\
\text { in absence of } \\
\text { oxygen. Not } \\
\text { affected by } \\
\text { electromagnetic } \\
\text { interference. } \\
\text { Monitoring area } \\
\text { is very wide. }\end{array}$ & $\begin{array}{l}\text { Affected by } \\
\text { ambient light } \\
\text { interference }\end{array}$ \\
\hline 2 & Electrochemical & $\begin{array}{l}\text { Measures toxic } \\
\text { gases in } \\
\text { relatively low } \\
\text { concentrations. } \\
\text { Wide range of } \\
\text { gases can be } \\
\text { detected }\end{array}$ & $\begin{array}{l}\text { Failures modes } \\
\text { are unrevealed } \\
\text { unless advanced } \\
\text { monitoring } \\
\text { technique used. }\end{array}$ \\
\hline 3 & Catalytic & $\begin{array}{l}\text { Simple, } \\
\text { measures } \\
\text { flammability of } \\
\text { gases and low } \\
\text { cost technology }\end{array}$ & $\begin{array}{l}\text { Requires air or } \\
\text { oxygen to work. } \\
\text { Can be poisoned } \\
\text { by lead, chlorine } \\
\text { and silicones }\end{array}$ \\
\hline 4 & Infra-red & $\begin{array}{l}\text { Uses only } \\
\text { physical } \\
\text { technique. No } \\
\text { unseen failure } \\
\text { modes. Can be } \\
\text { used in inert } \\
\text { atmospheres }\end{array}$ & $\begin{array}{lr}\text { Not all gases } \\
\text { have } \\
\text { absorption. } \\
\text { Sequential } \\
\text { monitoring is } \\
\text { slower on multi } \\
\text { point analyzers } \\
\text { and also more } \\
\text { user expertise } \\
\text { required }\end{array}$ \\
\hline 5 & Thermal & $\begin{array}{l}\text { Robust but } \\
\text { simple } \\
\text { construction. } \\
\text { Easy to operate } \\
\text { in absence of } \\
\text { oxygen. } \\
\text { Measuring } \\
\text { range is wide }\end{array}$ & $\begin{array}{l}\text { Reaction due to } \\
\text { heating wire. }\end{array}$ \\
\hline 6 & Metal oxide & $\begin{array}{l}\text { Mechanically } \\
\text { robust, works } \\
\text { well at constant } \\
\text { high humidity } \\
\text { condition. }\end{array}$ & $\begin{array}{l}\text { Susceptible to } \\
\text { contaminants and } \\
\text { changes due to } \\
\text { environmental } \\
\text { conditions. Non- } \\
\text { linear response } \\
\text { effects } \\
\text { complexity }\end{array}$ \\
\hline
\end{tabular}

\section{Conclusion}

The importance of environmental sensors has been increasing exponentially due to increase in toxic gas emission and at the same time imposition of several emission norms in the industries and permissible health hazards limits announced by
WHO. A review of different gas sensors was presented. The different sensing techniques discussed in this article includes catalytic gas sensors, electrochemical gas sensors, optical gas sensors, thermal conductivity gas sensors and acoustic gas sensors. Since the properties of an ideal sensor are defined by some variables which are; sensitivity, selectivity, high response time and fast recovery time. In view of this, all the sensors recently utilize the microfabrication and microfabrication techniques for the sensor fabrication. By adopting this technique, many solutions are offered including small size, low cost, low power consumption and as well possessing all the characteristics that classify them as an ideal sensor (119-121). Table 7 Comparison of gas detection sensor technological.

The development of semiconducting metal oxide as gas sensor has accelerated over last two decades and these sensors are widely used in sensing devices. Metal oxide semiconductor sensors have been shown to be sensitive to a large number of gases, with response varying with target gas concentration and device operating temperature. These properties can be tailored the specific environment in which the sensor is to be used. In future it is possible to design breathbased sensing device. Exhaled breath of animals contains almost 2000 volatile organic and inorganic compounds. Some of the volatile organic or inorganic compound's concentration changes significantly in diseased condition. Therefore, a sensitive, selective, cost effective and portable gas sensing system could successfully diagnose the disease and extent of illness.

\section{Acknowledgement}

The authors pay sincere tribute to Late Ms Deepika Rai Dhirendra Prasad who suddenly left this world and lived very short span of life, we the authors remember her on this occasion and pray Almighty God for peace of her holy soul. The authors are also thankful to Prof. P.S. Patil, Pro-ViceChancellor Shivaji University, Kolhapur and Mr Prashant Salvalkar for their constant encouragement and support during the progress of this review paper.

\section{Funding}

There is no any financial assistance from any government or non-government organization.

\section{Supporting information}

Not Applicable.

\section{Conflict of interest}

There are no conflicts to declare.

\section{References}

[1] Di Rosa Ambra Rita, L. Francesco, C. Federica and C. Vincenzo, J. Food Eng., 2017, 210, 62-75, doi:10.1016/j.jfoodeng.2017.04.024. 
[2] S. Buratti, D. Ballabio, G. Giovanelli, C.M. Zuluanga Dominguez, A. Moles, S. Benedetti and N. Sinelli, Anal. Chim. Acta, 2011, 697, 67-74, doi:10.1016/j.aca.2011.04.020.

[3] P. Muntner, D. Shimbo, R. M. Carey, J. B. Charleston, T. Gaillard, S. Misra, M. G. Myers, G. Ogedegbe, J. E. Schwartz, R. R. Townsend, E. M. Urbina, A. J. Viera, W. B. White, J. T. Wright Jr., Hypertension, 2019, 73, E35-E66, doi: 10.1161/HYP.0000000000000087.

[4] Oh Seok Kwon and Jyongsik Jang et.al., Nano Lett., 2015, 15, 6559-6567, doi:10.1021/acs.nanolett.5b02286.

[5] N. Silberman, R. Fergus, 2011 IEEE International Conference on Computer Vision Workshops (ICCV Workshops), 2011, 601 608, doi:10.1109/iccvw.2011.6130298.

[6] Z. Fang, Z. Zhao, Y. Wu et al., Proceedings of the 2004 International Conference on Information Acquisition, ICIA, 2004 , 84-87, doi: 10.1109/icia.2004.1373325.

[7] Ivarsson, P. Kikkawa, Y. Winquist, F. Krantz-r, C. Hayashi, K. Toko, K. Lundstr, I. Anal. Chim. Acta 2001, 449, 59-68, doi: 10.1016/S0003-2670(01)01349-6.

[8] A. Iwasaki, P. S. Pillai, Nat. Publ. Gr., 2014, 14, 315-328, doi: 10.1038/nri3665.

[9] E. Broughton, Environ. Health: A Global Access Science Source, 2005, 4, 1-6, doi: 10.1186/1476-069x4-6.

[10] L. Torsi, A. Dodabalapur, L. Sabbatini, P. Zambonin, Sensor. Actuat. B-Chem., 2000, 67, 312-316, doi: 10.1016/s09254005(00)00541-4.

[11] W. Chen, P. Liu, Y. Liu, Qi Wang, and W. Duan, Chen, Chem. Eng. J., 2018, 353, 115-125, doi:10.1016/j.cej.2018.07.110.

[12] J. Li, H. Yan, H. Dang, F. Meng, Opt. Laser Technol., 2021, 135, 106658, doi: 10.1016/j.optlastec.2020.106658.

[13] N. Sabri, S. A. Aljunid, M. S. Salim, R. B. Ahmad, J. Phys. Conf. Ser., 2013, 423, doi: 10.1088/1742-6596/423/1/012064.

[14] J. R. Stetter, W. R. Penrose, S. Yao, J. Electrochem. Soc. 2003, 150, 11-16, doi: 10.1149/1.1539051.

[15] N. R. Stradiotto, H. Yamanaka, M. V. B. Zanoni, J. Braz. Chem. Soc., 2003, 14, 159-173, doi: 10.1590/S010350532003000200003.

[16] J. Park, Nanostructured Semiconducting Metal Oxides for Use in Gas Sensors, 2010, 243, http://ro.uow.edu.au/theses/3441. [17] G. Eranna, B. C. Joshi, D. P. Runthala, R. P. Gupta, G. Eranna, B. C. Joshi, D. P. Runthala, R. P. Gupta, Crit. Rev. Solid State Mater. Sci., 2010, 29, 111-188, doi: 10.1080/10408430490888977.

[18] P. Ripka, Meas. Sci. Technol. Top., 2010, 21, doi: 10.1088/0957-0233/21/11/112001.

[19] V. Gupta, M. Sharma, N. Thakur J. Intell. Mater. Syst. Struct., 2010, 21, 1227-1243, doi: 10.1177/1045389X10381659.

[20] G. Park, C. R. Farrar, F. Lanza, S. Coccia, Smart Mater. Struct., 2006, 16, 1673-1683, doi: 10.1088/0964-1726/15/6/020.
[21] D. Matatagui, O. Kolokoltsev, N. Qureshi, E. Mejía-uriarte, A. Vázquez-olmos, J. M. Saniger, Sens. Actu. B Chem. 2017, 240, 497-502, doi: 10.1016/j.snb.2016.08.174.

[22] D. Matatagui, O. V. Kolokoltsev, N. Qureshi, E. V. Mejíauriarte, J. M. Saniger, Nanoscale, 2015, 7, 9607-9613, doi: 10.1039/c5nr01499a.

[23] Mizushima et al. (United States Patent, 1998), chap. US005747859A, pp. US005747859A.

[24] Tamon Kasajima, Hong Kong, ( United States Patent, 2012) chap. US008193805B2, pp. US008193805B2.

[25] Y. Zhang, W. Gao, Z. Song, Y. An, L. Li, Z. Song, W. Yu, Y. Wang, Sensor. Actuat. B-Chem, 2010, 147, 5-9, doi: 10.1016/j.snb.2009.11.044.

[26] L. Liao, H. B. Lu, J.C. Li, C. Liu, D.J. Fu, Appl. Phys. Lett., 2008, 91, 173110, doi: 10.1063/1.2800812.

[27] W. Wen, Introductory Chapter : What Is Chemical Sensor? In Progresses in Chemical Sensor; 2016, 3-8, doi: 10.5772/64626. [28] A. Lobnik, M. Turel, S. K. Urek, Adv. Chem. Sens., 2007, $3-$ 28, doi: $10.5772 / 31534$.

[29] I. Capek, Chapter 1 Nanotechnology and Nanomaterials. In Nanocomposite Structures and Dispersions: Science and Nanotechnology : Fundamental Principles and Colloidal Particles, Studies in Interface Science Book, 2006, 23, 1-69, doi: 10.1016/s1383-7303(06)80002-5.

[30] J.C. Tarafdar, S. Sharma, R. Raliya, Afr. J. Biotechnol., 2013, 12, 219-226, doi: 10.5897/AJB12.

[31] J. Jeevanandam, A. Barhoum, Y. S. Chan, A. Dufresne, M. K. Danquah, J. Nanotechnol., 2018, 9, 1050-1074, doi: 10.3762/bjnano.9.98.

[32] F. H. Garzon, R. Mukundan, R. Lujan, E. L. Brosha, Solid State Ionics, 2004, 175, 487-490, doi: 10.1016/j.ssi.2004.04.041. [33] G. Sberveglieri, R. Anchisini, R. Murri, C. Ercoli and N. Pinto, Sensor. Actuat. B-Chem., 1996, 32, 1-5, doi: 10.1016/09254005(96)80100-6.

[34] R. K. Nahar, Sensor. Actuat. B-Chem., 2004, 63, 49-54, doi: 10.1016/S0925-4005(99)00511-0.

[35] E. C. Dickey, O. K. Vargese, K. G. Ong, D. Gong, M. Paulose and C.A. Grimes, Sensors, 2002, 2, 91-110, doi:10.3390/s20300091.

[36] A. Ryzhikov, M. Labeau, A. Gaskov, Sensor. Actuat. BChem., 2005, 109, 91-96, doi: 10.1016/j.snb.2005.03.004.

[37] G. S. Devi, S.V. Manorama and V.J. Rao, J. Electrochem. Soc., 1998, 145, 1039- 1044, doi: 10.1149/1.1838385.

[38] Z. N. Adamian, H. V. Abovian and V. M. Aroutionian, Sens. Actuators B, 1996, 35, 241-243, doi: 10.1016/S09254005(96)90035-0.

[39] A. Cabot, A. Marsal, J. Arbiol and J. R. Morante, Sensor. Actuat. B-Chem., 2004, 99, 74-89, doi: 10.1016/j.snb.2003.10.032. 
[40] C. Xiangfeng, L. Xingqin and M. Guangyao, Sensor. Actuat. B-Chem., 2000, 65, 64-67, doi: 10.1016/S0925-4005(99)00430$\mathrm{X}$.

[41] H. J. Beie and A. Gnorich, Sensor. Actuat. B-Chem., 1991, 4, 393-399, doi: 10.1016/0925-4005(91)80141-6.

[42] P. Jasinski, T. Suzuki and H.U. Anderson, Sensor. Actuat. BChem., 2003, 95, 73-77, doi: 10.1016/S0925-4005(03)00407-6.

[43] Y. Li, W. Wlodarski, K. Galatsis, S.H. Moslih, J. Cole, S. Russo and N.Rockelmann, Sensor. Actuat. B-Chem., 2002, 83, 160-163, doi: 10.1016/S0925-4005(01)01031-0.

[44] G. Neri, A. Bonavita, G, Rizzo and S. Galvagno, J. Euro. Cer. Soc., 2004, 24, 1435-1438, doi: 10.1016/S0955-2219(03)00431$\mathrm{X}$.

[45] J. Du, Y. Wu, K. Choy, Thin Solid Films, 2006, 497, 42-47, doi: 10.1016/j.tsf.2005.09.169.

[46] M. Kaur, D. K. Aswal, J. V. Yakhmi, S. K.Gupta, Chemiresistor gas sensors: materials, mechanisms and fabrication. Science and Technology of Chemiresistor gas sensors. New York, Nova Science Publisher, 2007.

[47] J. Wollenstein, M. Burgmair, G. Plescher, T. Sulima, J. Hildenbrand, J. Bottner and I. Eisele, Sensor. Actuat. B-Chem., 2003, 93, 442-448, doi: 10.1016/S0925-4005(03)00168-0.

[48] C. Cantalini, M. Post, D. Buso, M. Guglielmi and A. Martucci, Sensor. Actuat. B-Chem., 2005, 108, 184-192, doi: 10/1016/j.snb.2004.11.073.

[49] A. Cruccolini, R. Narducci and R. Palombari, Sensor. Actuat. B-Chem., 2004, 98, 227- 232, doi: 10.1016/j.snb.2003.10.012.

[50] K. Unioersity, A. Katoch, J.-H. H. Kim, S. S. Kim, T. Maekawa, J. Tamaki, N. Miura, S. W. Choi, A. Katoch, J. Zhang, Sensor. Actuat. B-Chem., 2015, 15, 575-578 doi: 10.1166/jnn.2015.11505.

[51] M. Frietsch, F. Zudock, J. Goschnick, and M. Bruns, Sensor. Actuat. B-Chem., 2000, 65, 379-381, doi: 10.1016/S09254005(99)00353-6.

[52] V. R. Katti, A. K. Debnath, K. P. Muthe, M. Kaur, A. K. Dua, S. C. Gadkari, S. K. Gupta and V. C. Sahni, Sensor. Actuat. BChem., 2003, 96, 245-252, doi: 10.1016/S0925-4005(03)00532$\mathrm{X}$.

[53] P. Althainz, L. Schuy, J. Goschnick and H.J. Ache, Sensor. Actuat. B-Chem., 1995, 24-25, 448-450, doi: 10.1016/09254005(94)01393-4.

[54] G. Neri, A. Bonavita, G. Rizzo, S. Galvagno, S. Capone and P. Siciliano, Sensor. Actuat. B-Chem., 2006, 114, 687-695, doi: 10.1016/j.snb.2005.06.06.

[55] S. V. Ryabtsev, A. V. Shaposhnick, A. N. Lukin and E. P. Domashevskaya, Sensor. Actuat. B-Chem., 1999, 59, 26-29, doi: 10.1016/S0925-4005(99)00162-8.

[56] G. Neri, A. Bonavita, S. Galvagno, P. Siciliano and S. Capone, Sensor. Actuat. B-Chem., 2002, 82, 40-47, doi:
10.1016/S0925-4005(01)00987-X.

[57] M. Ogita, K. Higo, Y. Nakanishi and Y. Hatanaka, Appl. Surf. Sci., 2001, 175-176, 721-725, doi: 10.1016/S0169-

4332(01)00080-0.

[58] M. Ogita, S. Yuasa, K. Kobayashi, Y. Yamada, Y. Nakanishi and Y. Hatanaka, Appl. Surf. Sci., 2003, 212-213, 397-401, doi: 10.1016/S0169-4332(03)00122-3.

[59] J. Frank, M. Fleischer, H. Meixner and A. Feltz, Sensor. Actuat. B-Chem., 1998, 49, 110-114, doi: 10.1016/S09254005(98)00094-X.

[60] U. Lampe, E. Simon, R. Pohle, M. Fleischer, H. Meixner, H.P. Frerichs, M. Lehmann and G. Kiss, Sensor. Actuat. B-Chem., 2005, 111-112, 106-110, doi: 10.1016/j.snb.2005.06.041.

[61] M. Freischer, M. Seth, C.-D. Kohl and H. Meixner, Sensor. Actuat. B-Chem., 1996, 35-36, 290, doi: 10.1016/s09254005(97)80084-6.

[62] T. Doll, A. Fuchs, I. Eisele, G. Faglia, S. Groppelli and G. Sberveglieri, Sensor. Actuat. B-Chem., 1998, 49, 63-67, doi: 10.1016/S0925-4005(98)00037-9.

[63] G. Faglia, B. Allieri, E. Comini, L.E. Depero, L. Sangaletti and G. Sberveglieri, Sensor. Actuat. B-Chem., 1999, 57, 188-191, doi: 10.1016/S0925-4005(99)00079-9.

[64] Z. Jiao, M. Wu, J. Gu and X. Sun, Sensor. Actuat. B-Chem., 2003, 94, 216-221, doi: 10.1016/S0925-4005(03)00343-5.

[65] A. Forleo, L. Francioso, M. Epifani, S. Capone, A.M. Taurino and P. Siciliano, Thin Solid Films, 2005, 490, 68-73, doi: 10.1016/j.tsf.2005.04.022.

[66] W. Y. Chung, G. Sakai, K. Shimanoe, N. Miura, D.-D Lee and N. Yamazoe, Sensor. Actuat. B-Chem., 1998, 46, 139-145, doi: 10.1016/S0925-4005(98)00100-2.

[67] J. Xu, X. Wang and J. Shen, Sensor. Actuat. B-Chem., 2006, 115, 642-646, doi: 10.1016/j.snb.2005.10.038.

[68] R. Winter, K. Scharnagl, A. Fuchs, T. Doll and I. Eisele, Sensor. Actuat. B-Chem., 2000, 66, 85-87, doi: 10-1016/s09254005(99)00298-1.

[69] A. Gurlo, M. Barsan, M. Ivanovskaya, U. Weimer and W. Gopel, Sensor. Actuat. B-Chem., 1998, 47, 92-99, doi: 10.1016/S0925-4005(98)00033-1.

[70] D. Mutschall, K. Holzner and E. Obermeier, Sensor. Actuat. B-Chem., 1996, 35-36, 320-324, doi: 10.1016/S09254005(97)80089-5.

[71] E. Comini, G. Faglia, G. Sberveglieri, C. Cantalini, M. Passacatando, S. Santucci, Y. Li, W. Wlodarski and W. Qu, Sensor. Actuat. B-Chem., 2000, 68, 168, doi: 10.1016/S09254005(00)00484-6.

[72] M. Ferroni, V. Guidi, G. Martinelli, M. Sacerdoti, P. Nelli and G. Sberveglieri, Sensor. Actuat. B-Chem., 1998, 48, 285-288, doi: 10-1016/s0925-4005(98)00057-4.

[73] C. Imawan, F. Solzbacher, H. Steffes and E. Obermeier, 
Sensor. Actuat. B-Chem., 2000, 64, 193-197, doi: 10.1016/S09254005(99)00506-7.

[74] L. Chambon, J.P. Germain, A. Pauly, V. Demarne and A. Grisel, Sensor. Actuat. B-Chem., 1999, 60, 138-147, doi: 10.1016/S0925-4005(99)00259-2.

[75] I. T. Weber, R. Andrade, E. R. Leite and E. Longo, Sensor. Actuat. B-Chem., 2001, 72, 180-183, doi: 10.1016/S09254005(00)00648-1.

[76] M. Matsumiya, F. Qiu, W. Shin, N. Izu, N. Murayama and S. Kanzaki, Thin Solid Films, 2002, 419, 213-217, doi: 10.1016/S0040-6090(02)00762-9.

[77] J. A. Dirksen, K. Duval and T.A. Ring, Sensor. Actuat. BChem., 2001, 80, 106-115, doi: 10.1016/s0925-4005(01)00898-x. [78] I. Hotovy, J. Huran, P. Siciliano, S. Capone, L. Spiess and V. Rehacek, Sensor. Actuat. B-Chem., 2001, 78, 126-132, doi: 10.1016/S0925-4005(01)00802-4.

[79] I. Hotovy, V. Rehacek, P. Siciliano, S. Capone and L. Spiess, Thin Solid Films, 2002, 418, 9-15, doi: 10.1016/S00406090(02)00579-5.

[80] R. K. Sharma, M.C. Bhatnagar and G.L. Sharma, Sensor. Actuat. B-Chem., 1997, 45, 209-215, doi: 10.1016/S09254005(97)00295-5.

[81] L. Zheng, M. Xu and T. Xu, Sensor. Actuat. B-Chem., 2000, 66, 28-30, doi: 10.1016/S0925-4005(99)00447-5.

[82] F. Hossein-Babaei, M. Keshmiri, M. Kakavand and T. Troczynski, Sensor. Actuat. B-Chem., 2005, 110, 28-35, doi: 10.1016/j.snb.2005.01.010.

[83] A.M. Taurino, S. Capone, P. Siciliano, T. Toccoli, A. Boschetti, L. Guerini and S. Iannotta, Sensor. Actuat. B-Chem., 2003, 92, 292-302, doi: 10.1016/S0925-4005(03)00314-9.

[84] D. Manno, G. Micocci, R. Rella, A. Serra, A. Taurino and A. Tepore, J. Appl. Phys., 1997, 82, 54-59, doi: 10.1063/1.365848. [85] Y. K. Jun, H. S. Kim, J.H. Lee and S.H. Hong, Sensor. Actuat. B-Chem., 2005, 107, 264- 270, doi: 10.1016/j.snb.2004.10.010.

[86] K.D. Benkstein and S. Semancik, Sensor. Actuat. B-Chem., 2006, 113, 445-453, doi: 10.1016/j.snb.2005.03.122.

[87] A.M. Ruiz, A. Cornet and J.R. Morante, Sensor. Actuat. BChem., 2005, 111-112, 7-12, doi: 10.1016/j.snb.2005.06.040.

[88] I. Hayakawa, Y. Iwamoto, K. Kikuta and S. Hirano, Sensor. Actuat. B-Chem., 2000, 62, 55-60, doi: 10.1016/S09254005(99)00303-2.

[89] L.E. Depero, M. Ferroni, V. Guidi, G. Marca, G. Martinelli, P. Nelli, L. Sangaletti and G. Sberveglieri, Sensor. Actuat. BChem., 35-36, 381-383, doi: 10.1016/S0925-4005(97)80100-1.

[90] G. N. Chaudhari, A. M. Bende, A. B. Bodade, S.S. Patil and V.S. Sapkal, Sensor. Actuat. B-Chem., 2005, 115, 297-302, doi: 10.1016/j.snb.2005.09.014

[91] C.N. Xu, N. Miura, Y. Ishida, K. Matsuda and N. Yamazoe, Sensor. Actuat. B-Chem., 2000, 65, 163-165, doi: 10.1016/S0925-
4005(99)00413-X.

[92] B.T. Marquis and J.F. Vetelino, Sensor. Actuat. B-Chem., 2001, 77, 100-110, doi: 10.1016/S0925-4005(01)00680-3.

[93] X. Wang, N. Miura and N. Yamazoe, Sensor. Actuat. BChem., 2000, 66, 74-76, doi: 10.1016/s0925-4005(99)00410-4.

[94] P. Ivanov, J. Hubalek, K. Malysz, J. Prášek, X. Vilanova, E. Llobet and X. Correig, Sensor. Actuat. B-Chem., 2004, 100, 221 227, doi: 10.1016/j.snb.2003.12.065.

[95] Kaur M, Aswal DK, Yakhmi JV, Gupta SK. Chemiresistor gas sensors: materials, mechanisms and fabrication. Science and Technology of Chemiresistor gas sensors. New York, Nova Science Publisher, 2007.

[96] I. Lee, S.-J. Choi, K.-M.Park, S.S Lee, S. Choi, I.-D. Kim, \& C. O. Park, Sensor. Actuat. B-Chem., 2014, 197, 300-307, doi:10.1016/j.snb.2014.02.043.

[97] N. M. Hung, N. M. Hieu, N. D. Chinh, T. T. Hien, N. D. Quang, S. Majumder, D. Kim, Sensor. Actuat. B-Chem., 2020, 313, 128001, doi:10.1016/j.snb.2020.128001.

[98] M. Stankova, X. Vilanova, E. Llobet, J. Calderer, C. Bittencourt, J. J. Pireaux and X. Correig, Sensor. Actuat. B-Chem., 2005, 105, 271-277, doi: 10.1016/j.snb.2004.06.009.

[99] T. L. Royster, D. Chatterjee and G. R. Paz-Pujalt and C.A. Marrese, Sensor. Actuat. B-Chem., 1998, 53, 155-162, doi: 10.1016/s0925-4005(98)00312-8.

[100] W. Qu and W. Wlodarski, Sensor. Actuat. B-Chem., 2000, 64, 42-48, doi: 10.1016/S0925-4005(99)00481-5.

[101] H. Kawasaki, T. Ueda, Y. Suda and T. Ohshima, Sensor. Actuat. B-Chem., 2004, 100, 266-269, doi: 10.1016/j.snb.2003.12.052.

[102] Y. S. Kim, S. C. Ha, K. Kim, H. Yang, S. Y. Choi, Y. T. Kim, J. T. Park, C. H. Lee, J. Choi, J. Paek and K. Lee, Appl. Phys. Lett., 2005, 86, 213105, doi: 10.1063/1.1929872.

[103] L. G. Teoh, I. M. Hung, J. Shieh, W. H. Lai and M. H. Hon, Electrochem. Solid State Lett., 2003, 6, 108, doi: 10.1149/1.1585252.

[104] M Bendahan, R Boulmani, J. L. Seguin and K Aguir, Sensor. Actuat. B-Chem., 2004, 100, 320-324, doi: 10.1016/j.snb.2004.01.023.

[105] J. Tamaki, A. Hayashi, Y. Yamamoto and M. Matsuoka, Sensor. Actuat. B-Chem., 2003, 95, 111-115, doi: 10.1016/s09254005(03)00417-9.

[106] J. Liu, X. Wang, Q. Peng and Y. Li, Sensor. Actuat. B-Chem., 2005, 115, 481-487, doi: 10.1016/j.snb.2005.10.012.

[107] I. Raible, M. Burghard, U. Schlecht, A. Yasuda and T. Vossmeyer, Sensor. Actuat. B-Chem., 2005, 106, 730-735, doi: 10.1016/j.snb.2004.09.024.

[108] S. Capone, R. Rella, P. Siciliano and L. Vasanelli, Thin Solid Films, 1999, 350, 264-268, doi: 10.1016/s00406090(99)00045-0. 
[109] H. Nanto, T. Minami and S. Takata, J. Appl. Phys., 1986, 60, 482-484, doi: 10.1063/1.337435.

[110] P. Mitra, A.P. Chatterjee and H.S. Maiti, Mater. Lett., 1998, 35, 33, doi: 10.1016/s.0167-577x(97)00215-2.

[111] P. Nunes, E. Fortunato, A. Lopes and R. Martins, Int. J. Inorg. Mat., 2001, 3, 1129, doi: 10.1016/S1466-6049(01)001362.

[112] S.K. Hazra and S. Basu, Sensor. Actuat. B-Chem., 2006, 117, 177-182, doi: 10.1016/j.snb.2005.11.018.

[113] X. L. Cheng, H. Zhao, L.H. Huo, S. Gao and J.G. Zhao, Sensor. Actuat. B-Chem., 2004, 102, 248-252, doi: 10.1016/j.snb.2004.04.080.

[114] S. T. Shishiyanu, T. S. Shishiyanu and O. I. Lupan, Sensor. Actuat. B-Chem., 2005, 107, 379-386, doi: 10.1016/j.snb.2004.10.030.

[115] T. Mazingue, L. Escoubas, L. Spalluto, F. Flory, G. Socol, C. Ristoscu, E. Axente, S. Grigorescu, I.N. Mihailescu and N.A. Vainos, J. Appl. Phys., 2005, 98, 074312, doi: 10.1063/1.2076442. [116] H. Gong, J.Q. Hu, J.H. Wang, C.H. Ong and F.R. Zhu, Sensor. Actuat. B-Chem., 2006, 115, 247-251, doi: 10.1016/j.snb.2005.09.008.

[117] H. T. Wang, B. S. Kang, F. Ren, L. C. Tien, P. W. Sadi, D. P. Norton, S. J. Pearton and J. Lin, Appl. Phys. Lett., 2005, 86, 243503, doi: 10.1063/1.1949707.

[118] C. Wang, X. Chu and M. Wu, Sensor. Actuat. B-Chem., 2006, 113, 320-323, doi: 10.1016/j.snb.2005.03.011.

[119] PhD thesis Nisha R, http://hdl.handle.net/10603/63727.

[120] PhD thesis Mujawar Tabbasum Hanif, http://hdl.handle.net/10603/130710.

[121] $\mathrm{PhD}$ thesis Afzal Mohammad, http://hdl.handle.net/10603/160813.

\section{Author information}

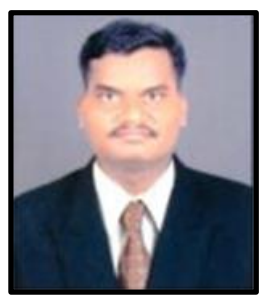

Mukesh N Padvi: He has completed master's degree in Physics from prestigious Kavgitri Bahinabai Choudhari North Maharashtra University, Jalgaon, India. He is having very bright educational career. He secured second position in the master's degree examination. Then he qualified SET examination. He is popular teacher and always helping students and colleagues in all academic and personal problems. He is working in School of Nanoscience and Technology since last May 2014.

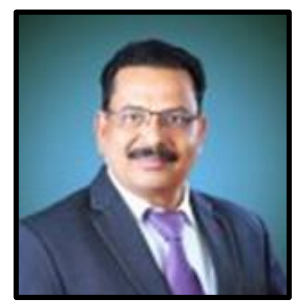

Annasabeb Moholkar: He is working as Assistant professor in Shivaji University, Kolhapur. His research area includes synthesis of nano-materials. He has published several papers of international repute. His main area of research is Gas sensing nanomaterials.

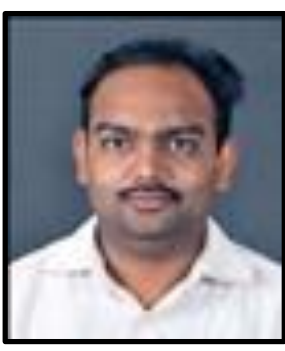

Saurabh Rai Dhirendra Prasad: He is working as Assistant Professor at DKTE Society's Textile and Engineering Institute, Ichalkaranji and also research scholar of Shivaji University, Kolhapur. He has qualified M.E. in Electronics and Telecommunication from KIT College of Engineering, PhD from Shivaji University Kolhapur. He has published several papers in journal of repute. He has also worked as reviewer for various international journals. He has about 16 years of teaching experience. He has expertise in the field of microwave engineering, audio and video engineering and digital signal processing.

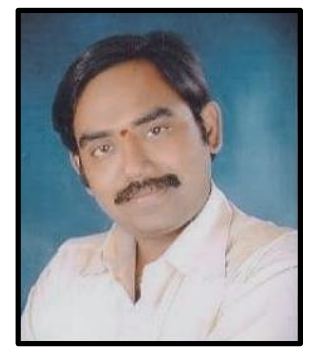

Neeraj Rai Dhirendra Prasad: He has completed master's degree in chemistry from Shivaji University, Kolhapur. Then, he completed PhD in chemistry from SPPU, Pune. He has written several research papers in the journal of international repute. Presently, he is trying to implement concept of nanotechnology in veterinary medicine and human medicine. He is interested in paranormal phenomenon and trying to connect to modern science.

Publisher's Note: Engineered Science Publisher remains neutral with regard to jurisdictional claims in published maps and institutional affiliations. 